\title{
HRVATSKA STRANKA PRAVA I PITANJE JEZIKA U DALMACIJI OD 1903. GODINE DO STVARANJA HRVATSKO-SRPSKE KOALICIJE 1906. GODINE
}

Vladislav B. Sotirović*

snovni istraživački cilj ovog članka je da prikaže politiku dalmatinskih političara iz redova Hrvatske stranke prava okupljenih oko Frane Supila i Ante Trumbića prema pitanju i problemu zvaničnog naziva jezika i upotrebe pisma u višenacionalnoj Dalmaciji u periodu od 1903. do 1906. Godine.

Ključne reči: jezik, pismo, Dalmacija, Hrvati, Srbi

"Krasno li je onda vrieme bilo, Dok je Hrvat bio svoj na svome;

Divno l'se je onda pjevat dalo,

A sad samo plakati se mora!"

August Harambašić (1861-1911), jedan od prvaka Hrvatske stranke prava Ante Starčevića inspirisan književnom slavom Dubrovnika iz Gundulićevog perioda (Harambašić A., "Ivan Franjin Gundulić", Izabrane pjesme, Zagreb, 1895, 169)

"Prošlost Dubrovniku, budućnost Beogradu"

Matija Ban 1887. g. na komemorativnoj sednici Srpske kraljevske akademije u Beogradu povodom Gundulićeve tristogodišnjice (“Matija Ban (r. 16. decembra 1818. - u. 14. marta 1903.", Srđ, t. 2, № 6,

Dubrovnik, 1903, 286-287)

\section{Uvod}

/ažnost problema jezika i pisma može se shvatiti iz činjenice da je pitanje zvaničnog naziva jezika kako u Dalmaciji tako i u Hrvatskoj i Slavoniji, tj. u čitavoj tzv. Trojednici (t.j. Trojednoj kraljevini), tokom XIX i XX veka bilo najuže povezano sa nacionalnim određenjem stanovništva ovih prostora, tj. Hrvata i Srba. Drugim rečima, pitanje naziva jezika je u suštini predstavljalo pitanje nacionalne determinacije, nacionalnog grupisanja i priznanja ili nepriznanja nacionalne egzistencije.

* Dr. Vladislav B. Sotirović is independent scholar and researcher, Lithuania, sotirovic@global-politics.eu. 
Ovo vremensko razdoblje u istoriji Dalmacije koje je trajalo tri godine, t.j. od 1903. do 1906. je predstavljalo novi period $u$ istoriji političkog života ove jadranske provincije, period u kome je pitanje naziva jezika igralo izuzetno važnu ulogu u političkom životu kako Hrvata tako i Srba.

Većina jugoslovenskih istoričara deli mišljenje da se gore navedeni vremenski period može smatrati novim dobom u jugoslovenskoj istoriji, period koji sigurno predstavlja razdoblje nove političko-stranačke aktivnosti Hrvata i Srba u Dalmaciji. ${ }^{1}$ Osnovna karakteristika ovog perioda je ta da se u ovom vremenskom razdoblju na teritoriji Dalmacije sprovodila politika tzv. "novog kursa", odnosno politički smer koji je ustanovljen na Dalmatinskom saboru u Zadru 1903., a koji je konačno doveo do Riječke i Zadarske rezolucije koje predstavljaju prekretnicu kako u hrvatsko-mađarskim tako i u hrvatsko-srpskim političko-nacionalnim odnosima. Riječkom rezolucijom potpisanom 3. oktobra 1905. od strane većine hrvatskih stranaka se zaključuje da se hrvatske stranke potpisnice rezolucije u političkoj borbi između Beča i Pešte opredeljuju za političku podršku Mađarima pod uslovom da Mađari pomognu Hrvatima da ujedine sve hrvatske zemlje. Kao jedan od uslova političke saradnje hrvatskih stranaka sa Mađarima je bio i taj da se Pešta odrekne politike mađarizacije Hrvatske i Slavonije uvođenjem mađarskog jezika kao službenog na ovim prostorima. Politika mađarizacije je u to vreme dobila novi zamah kada se 25 . marta 1903. na novoj zgradi železničke saobraćajne uprave u Zagrebu pojavio novi natpis ispisan zlatnim slovima na mađarskom jeziku: Magyar kiralyi allam vasutak ("Mađarske kraljevske državne železnice”). ${ }^{2}$ Tada je postojala mađarska uzrečica: “Čije železnice, onoga i zemlja". ${ }^{3}$ Nakon demonstracija u Zagrebu, ban Hrvatske i Slavonije, Kuen Hedervari (Károly Khuen-Héderváry, ban od 1883. do 1903.), je bio prinuđen da da izjavu kako će mađarski natpis biti zamenjen dvojezičnim natpisom na mađarskom i hrvatskom jeziku ali ta izjava nije zadovoljila hrvatsko javno mnjenje koje je tražilo da se na tzv. hrvatskoj teritoriji koristi isključivo hrvatski jezik. ${ }^{4}$ Isto tako, bilo je slučajeva da se na mađarskim železnicama kroz Hrvatsku-Slavoniju nije mogla kupiti karta do Rijeke već se morala tražiti karta za Fiumu pošto grad Rijeka nije postojao za mađarske službenike! Ovakvi slučajevi pokušaja (lingvističke) mađarizacije Hrvatske i Slavonije su samo ubrzali konsolidaciju hrvatskih nacionalnih snaga na liniji pravaške politike "novog kursa".

Sastanak u Rijeci, kao i samu Riječku rezoluciju su pripremili Dr. Ante Trumbić i Frano Supilo, koji će odigrati glavnu ulogu u politici "novog kursa" kako u Dalmaciji tako i u

\footnotetext{
${ }^{1}$ Na primer: Ibler J., Hrvatska politika 1903, Zagreb, 1913, 5-6; Isti., Hrvatska politika 1904-1906, Zagreb, 1914-1917, IV. Takođe, slično mišljenje se može naći i u sledećim radovima: Gross M., Vladavina Hrvatskosrpske koalicije, Institut društvenih nauka, Beograd, 1960; Pleterski J., "Politika 'novog kursa', jadranski kompromis i Slovenci", Jugoslovenski istorijski časopis, 3-4, Beograd, 1975; Ganza-Aras T., "Pojava politike 'novog kursa' u Dalmaciji g. 1903.", Radovi Filozofskog fakulteta Zadar, 4, Zadar, 1966; Lovrenčić R., Geneza politike 'novog kursa', Institut za hrvatsku povijest. Monografije 2, Zagreb, 1972.

${ }^{2}$ Politika mađarizacije Hrvatske-Slavonije je nastavljena i u narednim godinama. Tako je mađarska vlada donela "Lex Apponyi”, t.j. školski zakon, 1907. po kome su svi učenici nemađarskih školskih ustanova na čitavom prostoru zemalja krune Sv. Ištvana (u Hrvatskoj-Slavoniji takođe) bili obavezni da nauče mađarski jezik do svoje četvrte godine školovanja. Isto tako, je od te godine znanje mađarskog jezika bilo preduslov za zapošljavanje na državnim železnicama. Ova odluka je dočekana parlamentarnom opstrukcijom u Mađarskom parlamentu od strane poslanika iz Hrvatske-Slavonije (Kontler L., Millenium in Central Europe. A History of Hungary, Szeged, 1999, 298).

${ }^{3}$ Pavličević D., Povijest Hrvatske. Drugo, izmijenjeno i prošireno izdanje, Zagreb, 2000, 288-289.

${ }^{4}$ O Hedervarijevom banovanju vidi: Polić M., Ban Dragutin grof Khuen Héderváry i njegovo doba, Zagreb, 1901.
} 
Hrvatskoj i Slavoniji. Kao posledica Riječke rezolucije, dolazi 17. oktobra 1905. do sastanka srpskih političkih prvaka iz Trojednice - sastanka na kome je doneta odluka da se prihvate zaključci Riječke rezolucije, podrži borba Mađara i Hrvata protiv Beča, ali pod uslovom da se na čitavoj teritoriji Trojednice prizna nacionalna ravnopravnost Srba sa Hrvatima. Kao jedan od vidova priznanja ove nacionalne ravnopravnosti, srpski političari su zahtevali proglašenje hrvatsko-srpskog jezika kao zvaničnog jezika u Trojednici kao i ravnopravni tretman ćiriličnog pisma sa latinskim. Prema potpisnicima Zadarske rezolucije, odnosno srpskim političarima koji su podržavali hrvatsku politiku "novog kursa", priznanje nacionalnog jezika i pisma Srba automatski je značilo i priznanje postojanja srpske nacije u Trojednici, a uvođenjem dvočlanog naziva za jezik se potvrđivala nacionalna ravnopravnost Srba i Hrvata i izbegavala majorizacija jednih u odnosu na druge. Ovakvi stavovi srpskih političkih prvaka okupljenih oko programa Zadarske rezolucije su bili prirodan nastavak nacionalne politike srpskih političkih stranaka u Trojednici još od sredine XIX veka. Glavni značaj Riječke i Zadarske rezolucije je bio u tome što nakon podužeg vremena dolazi do prvog značajnijeg zajedničkog političkog nastupa Srba i Hrvata u Trojednici što je u svakom slučaju veoma neprijatno iznenadilo vladajuće političke krugove u Habsburškoj Monarhiji. Osnova za ovakvu hrvatsko-srpsku saradnju je predstavljalo priznanje nacionalne ravnopravnosti Srba sa Hrvatima, ravnopravnosti koja se pre svega ogledala u priznavanju nacionalnog jezika i pisma Srba. Prema tome, pitanje jezika i pisma je predstavljalo jednu od glavnih komponenti pravaške politike "novog kursa" kako za hrvatske tako i za srpske političare. Uspešno rešavanje ovog pitanja je i dovelo do sklapanja Hrvatsko-srpske koalicije 1906. na osnovama odluka Riječke i Zadarske rezolucije, koalicije koja je nakon pobede na izborima iste godine postala vladajućom političkom grupacijom u Hrvatskom saboru u Zagrebu.

\section{Geneza politike „novog kursa“}

Može se sa sigurnošću tvrditi da je početak politike "novog kursa" hrvatskih političkih stranaka prema Srbima i srpskom nacionalnom pitanju u Trojednici vezan za ime Stjepana Radića, jednog od osnivača i vođa Hrvatske pučke seljačke stranke (HPSS) 1904. Stjepan Radić je temelje nove politike Hrvata prema Srbima postavio početkom 1903. u tekstu Osnova rada za gospodarsku, narodnu i političku obranu Hrvatske proti madžarskoj političkoj sili u kome se zalaže za priznavanje srpskog nacionalnog imena, srpskog nacionalnog jezika, srpske zastave i srpskog nacionalnog pisma. Za uzvrat je od Srba tražio da priznaju Hrvatsku za svoju domovinu u kojoj bi bili ravnopravni sa Hrvatima sa pravom na očuvanje i negovanje nacionalnog pisma i jezika. Stjepan Radić je isticao da je potrebno da Hrvati neosporno priznaju "srpsko narodno ime u Hrvatskoj, srpsku narodnu zastavu i ćirilovsko pismo svuda, gdje Srbi žele njom pisati..." Pod priznanjem srpskog narodnog imena se podrazumevalo i priznanje srpskog narodnog jezika čija se formalna ravnopravnost sa hrvatskim narodnim jezikom imala ogledati u preimenovanju zvaničnog hrvatskog jezika u hrvatsko-srpski jezik koji bi se imao pisati kako latinicom tako i ćirilicom. Po Stjepanu Radiću, to je trebao biti najbolji put stvaranja "faktičkog narod-

\footnotetext{
${ }^{5}$ Korespondencija Stjepana Radića, knjiga 1, Zagreb, 1936, 406.
} 
nog jedinstva" Hrvata i Srba, jedinstva koje bi predstavljalo osnovu novog hrvatsko-srpskog političkog bloka protiv Beča i Pešte a naročito protiv politike mađarizacije Hrvatske i Slavonije uvođenjem javnih natpisa na mađarskom jeziku. Međutim, ukoliko Hrvati ne bi priznali srpsko nacionalno ime, jezik, zastavu i pismo onda bi se imali suočiti sa građanskim ratom protiv Srba koji bi Mađari umeli vešto da iskoriste protiv hrvatskih nacionalnih interesa. ${ }^{6}$ Ovde treba napomenuti da je strah od lingvističke mađarizacije Hrvatske-Slavonije u to vreme bio sasvim opravdan što se jasno videlo 1907. kada je mađarska vlada donela tzv. "Željezničku pragmatiku", odnosno zakon kojim se na svim ugarskim železnicama uvodi mađarski jezik. Ovaj zakon, koji se takođe odnosio i na teritoriju Hrvatske i Slavonije, je uveliko pokvario ionako loše hrvatsko-mađarske odnose. "Željeznička pragmatika" je ukinuta tek 1913., od kada su se hrvatski železničari mogli ponovo služiti "hrvatskim" jezikom koji je u osnovi bio srpski onako kako ga je Vuk Stefanović Karadžić standardizovao za Srbe na osnovu srpskog narodnog govora a hrvatski ilirci prihvatili kao zajednički i "hrvatski" i "srpski" iako sam Vuk nije nikada smatrao da ova dva naroda govore istim jezikom. Za Vuka je srpski jezik bio štokavski a hrvatski čakavski i delom kajkavski ali nikako štokavski. ${ }^{7}$ Inače, štokavski, kajkavski i čakavski nisu i ne mogu biti dijalekti jednog te istog etnojezika (kao što to hrvatska filologija uporno nastoji da dokaže) već su tri različita i odvojena jezika. ${ }^{8}$

Važnost političke saradnje Hrvata sa Srbima se najbolje može shvatiti iz podatka da je po popisu iz 1900. u Hrvatskoj i Slavoniji bilo ukupno 612.604 stanovnika srpske nacionalnosti što je činilo $25,52 \%$ od celokupnog stanovništva Hrvatske-Slavonije (bez Srema i Dalmacije). Takođe, rimokatolički Srbin iz Dubrovnika Lujo Bakotić je tvrdio da je pred kraj Prvog svetskog rata u Dalmaciji bilo 120,000 pravoslavnih Srba i 25,000 rimokatoličkih Srba. ${ }^{9} \mathrm{Na}$ ovom mestu je bitno prikazati nekoliko zvaničnih statističkih podataka nacionalne i verske pripadnosti južnoslovenskog elementa na prostoru AustroUgarske krajem XIX i početkom XX veka. Prema zvaničnim austrougarskim statističkim podacima na prostorima istorijske Mađarske, t.j., Krune Svetog Ištvana (uključujući Hrvatsku, Slavoniju i Vojnu granicu), brojčano stanje Srba i Hrvata 1890. je bilo: 6,1\% prema 9,0\%; 1900. - 5,5\% prema 8,7\% i 1910. - 5,3\% prema 8,8\%. U Bosni i Hercegovini 1910 . je bilo grkopravoslavnih $43,2 \%$, muhamedanaca $32,2 \%$, rimokatolika $23,0 \%$ i Jevreja $0,6 \%$. U istoj ovoj provinciji 1910 . je bilo Srba $42 \%$, Hrvata $21 \%$ i muhamedanaca $34 \%$.

Da su Srbi sa prostora Trojednice bili nezadovoljni svojim nacionalno-političkim statusom spram Hrvata u doba pisanja Radićeve Osnove rada...može se videti iz izveštaja Lazara Borđoskog upućenom Školskom savetu u Sremskim Karlovcima a koji se ticao srpskih čitanki za srpske osnovne škole u Hrvatskoj i Slavoniji. Prema ovom izveštaju, trebalo je poveriti nekom stručnjaku da sastavi novu srpsku čitanku iz dva razloga: a)

\footnotetext{
${ }^{6}$ Isto, 407. Slične stavove je Stjepan Radić zastupao još decembra 1901. što se može videti iz koncepta napisanog za uvodnik časopisa Hrvatska misao, koji se ticao pitanja priznavanja Srba u Trojednici (Isto, 376).

${ }^{7}$ Milosavljević P., Sistem srpske književnosti, Beograd, 2000, 110.

${ }^{8} \mathrm{O}$ hrvatskim stavovima o istorijatu hrvatskog književnog jezika videti u: Moguš M., Povijest hrvatskoga književnoga jezika, Zagreb, 1993.

${ }^{9}$ Bakotić L., Srbi u Dalmaciji od pada Mletačke republike do Ujedinjenja, Beograd, 1939, 5.

${ }^{10}$ Kann R. A., A History of the Habsburg Empire 1526-1918, Berkeley-Los Angeles-London, 1977, 605-608.
} 
"što su naše čitanke štampane istočnim narječjem (ekavicom, primedba V. B. S.) a zemaljske južnim (ijekavicom, primedba, V. B. S.), pa je zbog toga čitava zbrka kod djece, ne znaju ni sami kako da govore"; b) "što naša djeca uče iz njihovih čitanaka kojekakve njihove skovane, nakaradne riječi, i jednu trećinu od onoga što pročitaju ne razumu, dok im se ne protumači”. Iz gore navedenog, autor ovog izveštaja je zaključio da bi srpske veroispovedne osnovne škole u kraljevinama Hrvatskoj i Slavoniji trebale biti sastavljene tako 1) "da su članci (štiva) naizmjenice sa ćirilicom i latinicom štampani, a tako isto i pjesme za deklamovanje i pjevanje" i 2) "čitanka mora biti južnim narječjem štampana". ${ }^{11} \mathrm{Na}$ ovaj način bi se potvrdila nacionalna ravnopravnost Srba sa Hrvatima što je i bio osnovni preduslov za hrvatsko-srpsku političku saradnju koja je u to vreme bila neophodna kako bi se ublažio mađarski pritisak na Hrvatsku-Slavoniju nakon antisrpskih demonstracija u Zagrebu 1902. Hrvatsko-Slavonski ban Kuen Hedervari je umeo vešto da iskoristi te nerede u Zagrebu favorizujući srpske političke stranke protiv Hrvata ${ }^{12}$ što se ogledalo i u Kuenovoj naredbi da Srbi, posle antisrpskih septembarskih demonstracija, ponovo postave, na silu skinuti, ćirilični natpis na Srpskoj banci u Zagrebu. ${ }^{13}$ Međutim, u isto vreme grof Hedervari je preporučivao mađarskoj omladini da uči hrvatski jezik kako bi mogla da studira na Zagrebačkom sveučilištu u cilju ostvarenja mađarske "narodne misije" u Trojednici, koja se trebala sastojati u tome da Mađarska bude posrednička zemlja između Istoka i Zapada a to se moglo ostvariti samo mađarskom političkom dominacijom na Balkanu. Hedervarijeva ideja o učenju hrvatskog jezika od strane Mađara, lansirana u članku koji je štampan u Budapesti Hirlapu, je imala praktični politički cilj da pridobije Hrvate za sjedinjenje Dalmacije sa Hrvatskom i Slavonijom ali pod mađarskom administrativnom upravom u okvirima Austro-Ugarske. ${ }^{14}$ Autor članka je naglašavao da je "dominacija Balkana preko Hrvatske i hrvatskog jezika ...san Mađara". ${ }^{15}$ Međutim, kako Hrvati, tako su i Srbi shvatili šta se krije iza ovakve lingvističke politike bana-grofa Kuena Hedervarija i nastavili su još oštrije da se bore za svoja nacionalna prava. Tako je tradicionalne srpske zahteve u to vreme iznela i grupa Srba na svojoj javnoj skupštini u Dvoru 22. decembra 1903. tražeći "da sabor donese zakon o ravnopravnosti srpskog naroda sa hrvatskim,

\footnotetext{
${ }^{11}$ Arhiv Srpske akademije nauka i umetnosti, "Lazar Borđoski Školskom savetu, Karlovac, 11./24. aprila 1903.", Sremski Karlovci, Školski savet, broj 196/1903. Na neophodnost priznavanja srpskog naroda, jezika i pisma i njegove pravne i faktičke ravnopravnosti sa hrvatskim narodom, jezikom i pismom u Trojednici ukazivao je i hrvatski političar Đuro Surmin u svom pismu Tihomiru Ostojiću od 2. maja 1903. (Rukopisno odeljenje Matice srpske, broj. 6.995).

${ }^{12}$ Vermes G. P., "South Slav Aspirations and Magyar Nationalism in the Dual Monarchy", Banac I., Ackerman G., Szporluk R. (eds.), Nations and Ideology. Essays in Honor of Wayne S. Vucinich, New York, 1981, 177-200; Pavličević D., Povijest Hrvatske. Drugo, izmijenjeno i prošireno izdanje, Zagreb, 2000, 290-291.

${ }^{13}$ Kršnjavi I., Zapisci, knjiga I, Zagreb, 1927, 273. Ova zabeleška Ise Kršnjavija nosi datum 30. maj 1903.

${ }^{14}$ Prema austro-mađarskom Ausgleich-u iz 1867, Hrvatska, Slavonija, Srem i Vojvodina su pripali Ugarskoj (Translajtaniji) dok su Istra, Dubrovnik, Boka Kotorska, Dalmacija, Kranjaska, Štajerska i Koruška pripali Austriji (Cislajtaniji). Bosna i Herzegovina su nakon austrougarske okupacije 1878. bile pod zajedničkom carsko-kraljevskom upravom. O ovoj problematici videti opširnije u: Gross M, Szabo A., Prema hrvatskome građanskom društvu. Društveni razvoj u civilnoj Hrvatskoj i Slavoniji šezdesetih i sedamdesetih godina 19. Stoljeća, Zagreb, 1992, 191-251. O južnoslovenskom pitanju u Austro-Ugarskoj nakon Ausgleicha videti u: Seton-Watson R. W., The Southern Slav Question, London, 1911.

${ }^{15}$ Obzor, 30./6. 2. 1902., "Hrvati i Mađari”; Isto, "Izmirenje Hrvata s Mađarima”.
} 
Iskustva i pouke iz prošlosti

srpskog imena sa hrvatskim, ćirilice sa latinicom, i da se uzakoni slobodno i neograničeno upotrebljavanje srpske narodne zastave". ${ }^{16}$

Srpske političke stranke u Trojednici su u svoje političke programe objavljene 1903. unele posebne odredbe o nazivu jezika. Tako je Srpska narodna samostalna stranka istakla da će zahtevati "prema načelu ravnopravnosti priznanje srpskog naroda u trojednoj kraljevini, i prema tome da se u svakom unutrašnjem zakonu, naredbi ili drugom važnom službenom činu, gdje je riječ o narodu kraljevina Hrvatske i Slavonije ili o njegovom jeziku, dostojno uvaži ime i jezik srpskoga naroda". Samostalci su posebno naglasili da će prilikom revizije Hrvatsko-ugarske Nagodbe (iz 1868./1873.) tražiti da se "uz hrvatski narod i jezik prizna i srpski narod i jezik, a ćirilici, kao pismu srpskoga naroda, prizna potpuna ravnopravnost s latinicom u svima zajedničkim zvanjima na teritoriji kraljevina Hrvatske i Slavonije". 17

Na osnovu ovakvog svog programa iz 1903., Radićevu politiku saradnje sa Srbima u Trojednici predloženu u Osnovama rada... je sredinom 1903. godine prihvatila i najuticajnija srpska politička stranka u Hrvatskoj-Slavoniji - Srpska narodna samostalna stranka. Duh politike "novog kursa" i saradnje Hrvata i Srba u Trojednici se jasno može videti iz zaključaka sednice Središnjeg odbora Srpske narodne samostalne stranke, održane u Zagrebu 11. juna 1903. Kao vidljivi dokaz promenjene politike prema Hrvatima, Središnji odbor srpskih samostalaca je doneo odluku da se naziv stranačkog lista Srbobran preimenuje u Novi Srbobran i imenuje njegov novi urednik - Svetozar Pribićević. Ove promene su nagoveštavale da će stranka u svom budućem političkom radu napustiti pređašnji kurs s kraja XIX veka koji je jednim delom počivao na "štokavskoj ideologiji Srpstva" koju je stranka favorizovala za vreme banovanja Kuena Hedervarija sve do zagrebačkih antisrpskih demonstracija 1902. koje su bile formalno isprovocirane štampanjem članka Nikole Stojanovića "Srbi i Hrvati" u kome se poricala nacionalna posebnost Hrvata s obzirom da im je i književni i govorni jezik bio štokavski dijalekt, dijalekt koji su i autor teksta i ideolozi Srpske samostalne stranke punopravno smatrali osnovnim nacionalnim obeležjem Srpstva i srpskim izvornim narodnim jezikom. Po Stojanoviću, Hrvati nisu uspeli da se formiraju kao nacija nakon Francuske buržoaske revolucije (1789.-1794.) jer među njima nije postojala svest o zajedničkom međusobnom pripadništvu, zajedničkom poreklu, zemlji, običajima, kulturi i iznad svega jeziku. ${ }^{18}$ Prema tome, kako za Stojanovića tako i za srpske samostalce do 1902., Hrvati su mogli biti samo deo srpske nacije prema nemačko-romantičarskoj formulu da jezik određuje nacionalnu pripadnost.

Međutim, na već spominjanoj sednici Središnjeg odbora Srpske narodne samostalne stranke, njeno političko rukovodstvo je u duhu politike "novog kursa" odbacilo "ideologiju štokavskog Srpstva" zasnovanu na tezi Vuka Stefanovića-Karadžića iz 1836./1849. da su svi pripadnici Južnih Slovena koji govore i pišu štokavskim dijalektom izvorno etnički Srbi. ${ }^{19}$

\footnotetext{
${ }^{16}$ Arhiv Hrvatske u Zagrebu, Predsednički spisi zemaljske vlade, "Sreski načelnik iz Dvora velikom županu Budi Budisavljeviću, Dvor, 25. decembar, 1903.”, kutija 648, dokument 2801, 1903.

${ }^{17}$ Program Srpske narodne samostalne stranke, Zagreb, 1903, 4-7.

${ }^{18}$ Ovaj Stojanovićev članak je izvorno štampan u Srpskom književnom glasniku, 6/37, 1. avgusta 1902., Beograd, 1149-1159.

${ }^{19}$ Ovakav stav je zastupao između ostalih slavnih slovenskih filologa iz XIX veka i Pawel J. Šafařik: Šafařik P. J., Geschichte der slawischen Sprache und Literatur, Buda, 1826. O Vukovom životu i radu vidi u: Duncan W., The Life and Time of Vuk S. Karadžić, Oxford, 1970.
} 
Središnji odbor srpskih samostalaca je prihvatio politiku saradnje sa hrvatskim opozicionim strankama u cilju "odbrane samostalnosti Kraljevine Hrvatske i Slavonije od mađarske imperijalističke politike i srpsku narodno-crkvenu autonomiju od integracije od strane ugarskih državnih vlasti”. Osnova novog političkog programa srpskih samostalaca je počivala na odbrani autonomije srpskog naroda u Ugarskoj i Trojednici i zalaganju za nacionalnu ravnopravnost Hrvata i Srba koja se mogla i trebala ostvariti usvajanjem hrvatsko-srpskog jezika kao zvaničnog jezika u Trojednici i poštovanjem ravnopravne upotrebe ćirilice sa latini$\mathrm{com}^{20}$ Srpski samostalci su na svojoj skupštini u Osjeku u jesen iste godine još jednom potvrdili da prihvataju politiku "novog kursa" ukoliko se "uzakoni ravnopravnost srpskog imena sa hrvatskim, ćirilice sa latinicom, srpske pravoslavne crkve sa rimokatoličkom i slobodno i neograničeno upotrebljavanje srpske narodne zastave". ${ }^{21} \mathrm{Na}$ ovim osnovama su juna 1903. hrvatski politički radnici iz Dubrovnika izrazili spremnost da pregovaraju sa Srbima iz Dalmacije i Srpskom narodnom radikalnom strankom. ${ }^{22} \mathrm{U}$ isto vreme su i neki predstavnici Hrvatske stranke prava izrazili želju da radi sporazuma sa Srbima ovima priznaju poseban nacionalni identitet, jezik i pismo, ${ }^{23}$ a ne da ih kao do tada tretiraju kao deo hrvatskog etnonacionalnog korpusa. Tako su sredinom 1903. postavljeni temelji politike "novog kursa" (političke i među-nacionalne saradnje) Hrvata i Srba u Trojednici. ${ }^{24}$

Duh te nove politike je jasno izražen u Programu Srpske narodne radikalne stranke u Hrvatskoj i Slavoniji iz septembra 1903. a naročito u onim njegovim tačkama koje se odnose na pismo i jezik kao osnovnih nacionalnih determinatora. Srpski radikali su se u ime jednakosti i ravnopravnosti srpskog sa hrvatskim narodom u Hrvatskoj i Slavoniji zalagali "da se u svakom zemaljskom zakonu i svakom drugom službenom aktu upotrebi naziv 'hrvatski i srpski narod', 'hrvatski i srpski jezik"'; "da se uzakoni potpuna ravnopravnost ćirilice sa latinicom", "u hrvatskim oblastima da je službena latinica, u srpskim pak ćirilica. No u svim oblastima ima svako prava da se služi kod sviju vlasti bilo latinicom, bilo ćirilicom, a dužnost je vlasti da rešavaju onim slovima, kojim su podnesci predani", 25 "da se uzakoni slobodna upotreba ćirilice u zajedničkim finansijskim, poreskim, poštanskim i brzojavnim službama domovine naše", "da se uzakoni pravo srpskom narodu, da može otvarati svoje narodne veroispovedne osnovne, srednje i stručne škole" u kojima bi se nastava izvodila na nacionalnom jeziku Srba i konačno "... da se na filozofskom fakultetu Franje Josifa I u Zagrebu otvori katedra za istoriju srpskog naroda i istoriju srpske književnosti sa stručnim pro-

\footnotetext{
20 "Zapisnik sa sednice Središnjeg odbora Srpske samostalne stranke održane 11. juna 1903. u Zagrebu" i "Zaključci Središnjeg odbora Srpske samostalne stranke doneti cirkularno juna 1903. g.", Fotokopije dokumenata se nalaze kod advokata Vladimira Ivkovića u Zagrebu, Krestić Đ. V., Građa o Srbima u Hrvatskoj i Slavoniji (1848-1914), knjiga II, Beograd, 1995, 351-354.

${ }^{21}$ Arhiv Hrvatske u Zagrebu, "Uprava grada Osijeka banu Teodoru Pejačeviću - dostavlja rezoluciju usvojenu na skupštini Srpske samostalne stranke održane u Osijeku, Osijek, 23. novembra 1903.", Predsednički spisi zemaljske vlade, broj 6732, 1903.

${ }^{22}$ Vojvođanski muzej, Radikalna stranka, "Pismo Antuna Puljezija i Dr. Kneževića Jaši Tomiću, Dubrovnik, 18. Jun 1903.", broj 4037/99.

${ }^{23}$ Krestić Đ. V., Građa o Srbima u Hrvatskoj i Slavoniji (1848-1914), knjiga II, Beograd, 1995, "Cirkular Šandora Brešćenskog, Pleso, 4. novembra, 1903.", 371.

${ }^{24}$ Perić I., Povijest Hrvata, Zagreb, 1997, 205-208.

${ }^{25}$ Potrebno je naglasiti da je pitanje upotrebe ćirilice na teritoriji Hrvatske-Slavonije rešio Hrvatski sabor Zakonom od 14. maja 1887. (o tome videti u: Miladinović Z., Tumač povlastica, zakona, uredaba $i$ drugih naređenja srpske narodne crkvene avtonomije u Ugarskoj, Hrvatskoj i Slavoniji, Novi Sad, 1897, 100-101).
} 
fesorom Srbinom" koji bi nastavu izvodio na srpskom jeziku. Sastavljači ovog radikalskog programa su napominjali da su "jezik, slova, osobine, običaji naroda, proizvod mnogovekovnog razvitka" i integralni deo nacionalnog bića. Shodno tome, svaka nacija ima pravo da neguje i razvija svoj jezik i pismo i ne dozvoli da izgubi nacionalni identitet nametanjem tuđeg jezika i pisma. Konačno, Program Srpske narodne radikalne stranke je sugerisao hrvatskim vlastima da zarad nacionalne ravnopravnosti Hrvata i Srba u Trojednici poštuje odluku Hrvatskog sabora od 11. maja 1867. "da trojedna kraljevina priznaje narod srpski, koji u njoj stanuje, kao narod sa hrvatskim narodom istovjetan i ravnopravan". Ta se ravnopravnost najbolje ogledala u odluci istog Sabora početkom januara 1867. da je hrvatski ili srpski jezik službeni jezik u Trojednici što je samo bila potvrda prethodne odluke Jugoslavenske akademije u Zagrebu "da Akademija jezik svoj nareče hrvatskim iliti srpskim". ${ }^{26}$ Ukratko, zalažući se za potpunu ravnopravnost Srba i Hrvata radi njihovog zajedničkog političkog nastupa, srpski radikali su zahtevali isto kao i srpski samostalci da se priznavanjem posebnog nacionalnog pisma i jezika Srba ujedno prizna i postojanje srpske nacije pored hrvatske kao i da se prizna potpuna ravnopravnost upotrebe jezika i pisma ova dva naroda. ${ }^{27}$

Politika "novog kursa" je od svih istorijskih i etničkih hrvatskih zemalja imala najviše pristalica u Dalmaciji. Nije slučajno da su upravo dalmatinski političari južnoslovenskog porekla najotvorenije prihvatili politiku "novog kursa", tj. politiku koja je svesno i aktivno bila usmerena ka slabljenju pa po mogućnosti i uništenju Austro-Ugarske Monarhije. Razlog za ovu činjenicu je bio najviše praktično-ekonomske prirode a uzrokovan je austrougarskom politikom zanemarivanja ekonomskog razvitka Dalmacije. To se jasno može videti iz potpisanog trgovačkog ugovora između Austro-Ugarske i Italije 1891. koji je imao za cilj da politički i ekonomski čvršće priveže Italiju za Trojni Savez. Takozvanom "vinskom klauzulom" ovog ugovora privreda Dalmacije je znatno degradirana jer je Italija dobila velike carinske povlastice za izvoz vina u Austro-Ugarsku. S obzirom da je tržište Dvojne Monarhije bilo preplavljeno italijanskim vinom, vinska industrija Dalmacije, koja je ujedno predstavljala i glavnu industrijsku granu ove austrijske pokrajine, je faktički bila uništena. Dalmatinsko vino - glavni privredni izvozni proizvod Dalmacije - je bilo potpuno potisnuto sa austrougarskog tržišta što je nanelo nenadoknadivi ekonomski udarac ovoj pokrajini i njenom ionako siromašnom stanovništvu. ${ }^{28}$ Sem vina, po tom ugovoru iz 1891. je Austro-Ugarska uvozila iz Italije južno voće i povrće, upravo one poljoprivredne proizvode koji su se mogli proizvesti i u Dalmaciji, a izvozila u Italiju konje, drvo i svilenu bubu koji se nisu mogli naći ili proizvoditi u Dalmaciji. ${ }^{29}$ Kao direktna posledica lošeg eko-

\footnotetext{
${ }^{26}$ Život Dra Jovana Subotića, knjiga III, Novi Sad, 1905, 222-224; Dnevnik sabora trojedne kraljevine Dalmacije, Hrvatske i Slavonije godine 1865-1867, Zagreb, 1967, 708-709; Kušlan D. - Suhaj M., Spisi saborski sabora kraljevinah Dalmacije, Hrvatske i Slavonije od godine 1865-1867, knjiga I, Zagreb, 1962, 159; Krestić Đ. V. - Ljušić R., Programi i statuti srpskih političkih stranaka do 1918. godine, Beograd, 1991; Vučetić I., Zbirka uredaba u stvarima srpske pravoslavne narodno-crkvene avtonomije, Novi Sad, 1897, 197-198; Narodni glasnik, dodatak broj 35, 1903, Program Srpske narodne radikalne stranke u kraljevini Hrvatskoj i Slavoniji (primljen na zboru Srpske narodne radikalne stranke u Okučanima 20. septembra 1903.).

${ }^{27}$ Politički program Srpske narodne radikalne stranke u Ugarskoj i Hrvatskoj i Slavoniji, Novi Sad, 1904, 8.

${ }^{28}$ O ovom problemu videti opširnije u: Ozanić S., Poljoprivreda Dalmacije u prošlosti, Split, 1955; Zotti I., O razvitku poljodjelstva u Dalmaciji od godine 1848. do 1898, Beč, 1901; Jelinović Z., Borba za jadranske pruge $i$ njeni ekonomski ciljevi, Zagreb, 1957.

${ }^{29}$ Arhiv trgovačko-obrtničke komore u Splitu, sveska 192/1903, broj 118, Historijski arhiv u Splitu; Brzopisna izvješća Pokrajinskoga sabora dalmatinskoga, godina 1902, 563.
} 
nomskog stanja u Dalmaciji krajem XIX i početkom XX veka se javlja problem iseljavanja. Samo se u periodu od 1901. do 1905. iselilo iz Dalmacije više od 20.000 stanovnika što je bio glavni pokazatelj postojanja duboke ekonomske depresije u ovim krajevima. Od iseljavanja je Dalmacija imala nenadoknadivu štetu jer je odlazilo uglavnom radno sposobno stanovništvo pa je u sektoru poljoprivrede nastajala još veća pustoš. ${ }^{30}$ Može se zaključiti da je "vinska klauzula" koja je prouzrokovala "najužasniju krizu, što je dosada doživela Dalmacija na ekonomskom polju" ${ }^{31}$ predstavljala kap koja je prelila čašu dalmatinske gorčine prema politici Beča i Pešte i naterala hrvatske stranke iz Dalmacije da se okrenu saradnji kako sa mađarskom opozicijom tako i sa srpskim političkim strankama u Dalmaciji. Tako je Dalmatinski sabor 1903. poslao u Beč zahtev žitelja Dalmacije da se više ne može tolerisati popustljiva ekonomska politika Austro-Ugarske prema Italiji jer takva politika vodi potpunom ekonomskom uništenju Dalmacije. ${ }^{32} \mathrm{Na}$ drugoj strani, nezadovoljstvo Dalmacije takvom privrednom politikom Austro-Ugarske, centralna vlada u Beču je nazivala "uskogrudošću", "težnjama ka partikularizmu" pa čak i neshvatanjem "viših" potreba države i "zaostalošću" Dalmatinaca koji su tobože bili "nesposobni" za rad i ekonomsko privređivanje. ${ }^{33}$

\section{Lingvistički nacionalizmi u Dalmaciji i nastanak politike „novog kursa" dalmatinskih pravaša}

Rešenje za izlaz iz ovakvog stanja u kome se nalazila čitava Trojednica je u to vreme traženo u saradnji svih hrvatskih političkih snaga kako bi se formirala ili autonomna ujedinjena hrvatska federalna jedinica u okviru Austro-Ugarske ili nezavisna hrvatska država van Dvojne Monarhije. Vođstvo u ovoj novoj borbi za ujedinjenje hrvatskog naroda i hrvatskih zemalja je preuzela na sebe grupa mladih političara iz Hrvatske stranke prava koja je sebe nazivala naprednjacima. Tako je hrvatski političar iz Dalmacije - Josip Smodlaka - u leto 1902. isticao da je jedini izlaz iz tadašnjeg teškog političko-ekonomskg stanja, za koje je tvrdio da je posledica dualističkog i centralističkog političkog sistema Austro-Ugarske, da "narod hrvatski postane gospodar svoje sudbine, da Hrvat bude svoj na svome!"34 Naprednjak M. Marjanović se zalagao za novi politički pokret koji bi doneo "pravi preporod i početak novog života", tj. slobodu i nezavisnost hrvatskom narodu i ujedinjenje svih hrvatskih zemalja pod jedinstvenom političkom upravom. ${ }^{35}$ Program "novog kursa" naprednih pravaša je najsažetije skicirao jedan od njihovih vođa, dalmatinski političar - Ante Trumbić - sledećim rečima: "Nužda našeg opstanka sili nas, da istupimo iz ove državnopravne sveze i

\footnotetext{
${ }^{30}$ Milićević A., "O iseljavanju, osobitim obzirom na prilike u Dalmaciji", Glasnik Matice dalmatinske, knjiga II, sveska 1, Zadar, 1903.

${ }^{31}$ Spomenica Vinske udružbe od 24. 5. 1902, Historijski arhiv u Splitu.

${ }^{32}$ Brzopisna izvješća Pokrajinskoga sabora dalmatinskoga, godina 1903, 356-358.

${ }^{33}$ Artmann F., Wirtschaftliche Faktoren in Dalmatien, Wien, 1907; Karaman I., Privredni razvitak Dalmacije pod austrijskom upravom, Split, 1965, 648.

${ }^{34}$ Smodlaka J., Dva govora što ih je izrekao dr Josip Smodlaka, narodni poslanik u hrvatskom saboru u Zadru, dne 15. i 22. srpnja 1902, Zadar, 1902, 81.

${ }^{35}$ Marjanović M., "Hrvati i Talijani", Hrvatski pokret, II, Dubrovnik, 1904, 14; isto, Hrvatski pokret, I, Dubrovnik, $1903,3$.
} 
da se uhvatimo u kolo naše braće...; Hrvatska, Slavonija, Bosna i Hercegovina, Dalmacija i ostale okolišne hrvatske zemlje jedno su tijelo i to po teritoriji, jeziku, etnosu, interesu, pa im je i budućnost zajednička, bez obzira sretna ili nesretna" ${ }^{36}$

Polazna tačka programa dalmatinskih pravaša, zastupnika politike "novog kursa", bilo je administrativno-upravno jedinstvo Dalmacije sa Banskom Hrvatskom na osnovu nacionalne svesti o jedinstvu po jeziku, veri, imenu i kulturi. ${ }^{37}$ Za pravaše iz redova politike "novog kursa", narod koji je bio ugrožen morao se boriti za svoje političko-ekonomsko oslobođenje prevashodno sa pozicija prirodnog prava pod kojim se podrazumevalo da svaka nacija ima "prirodno pravo" da živi ujedinjena u okvirima svoje sopstvene nacionalne države. ${ }^{38}$ Po njima, jezik je predstavljao jednu od najbitnijih nacionalnih komponenti i determinanti pa su shodno ovom lingvističkom principu nacionalnog određenja tražili da se sve zemlje u kojima se govorilo "hrvatskim" jezikom ujedine u jedinstvenu političku zajednicu hrvatskog naroda. Međutim, ovakav lingvistički princip nacionalnog određenja i političkog ujedinjenja je mogao dovesti do otvorenog sukoba sa sličnom političkom ideologijom Srba naročito oko Bosne i Hercegovine za koju su i Hrvati i Srbi smatrali da je njihova nacionalna teritorija jer je njeno stanovništvo govorilo hrvatskim, odnosno srpskim, jezikom (štokavskim narečjem). Može se zaključiti da je za novu generaciju Hrvatske stranke prava pitanje sjedinjavanja Dalmacije sa Hrvatskom i Slavonijom, koje bi politički ujedinjene predstavljale jaku privlačnu tačku za dalje sjedinjavanje hrvatskog naroda iz Istre, Međumurja, Rijeke, Bosne i Hercegovine, bio osnovni nacionalni zadatak. Ovakav politički program je bio u direktnoj suprotnosti sa namerama Beča i Pešte da održe status quo na jugu Dvojne Monarhije pa su stoga hrvatsko-dalmatinski političari "novog kursa" tražili radi realizacije svojih ciljeva masovnije političko sudelovanje udružene građanske opozicije svih antibečkih i antipeštanskih snaga bez obzira na njihove međusobne unutrašnje razlike. ${ }^{39}$ Ova nova naprednjačka linija u redovima Hrvatske stranke prava iz Dalmacije se prvenstveno zalagala za realizaciju državnopravne politike starih pravaša Ante Starčevića iz druge polovine XIX veka ali putem beskompromisne borbe protiv Beča i postepenom realizacijom svog političkog programa. ${ }^{40}$ Politika "novog kursa" u Dalmaciji je faktički predstavljala reakciju na dalmatinske pristalice Hrvatske narodne stranke koji su bili spremni na politički kompromis sa Bečom sprovodeći politiku oportunizma. Argumentacija dalmatinskih pravaša "novog kursa" za svoju antibečku i antipeštansku politiku se pored ukazivanja na ekonomsko propadanje Dalmacije bazirala velikim delom i na dokazivanju o sistematskom zapuštanju hrvatskog jezika i lošem školskom sistemu u kome su zapostavljeni predmeti iz nacionalne istorije, geografije i kulture a prvenstveno izučavanje kako maternjeg jezika Hrvata tako i književnosti pisane na njemu.

\footnotetext{
${ }^{36}$ Trumbić A., Govor izrečen na sjednici 18. veljače 1897. Dalmatinskog sabora pri raspravi o zemaljskom proračunu, Zadar, 1897, 11-12. Ovaj Trumbićev govor je, međutim, dosta obojen velikohrvatskim teritorijalnim šovinizmom koji je objektivno postojao iza paravana politike "novog kursa" i proklamovane političke saradnje sa Srbima a koji su srpski političari iz Trojednice koji su se zalagali takođe za politiku "novog kursa” ili zanemarivali ili previđali.

${ }^{37}$ Majstorović I., "Besjeda biračima pri pohodu izbornog kotara, listopada 1902", Zadar, 1903, 46.

${ }^{38}$ Isto, 5-6.

${ }^{39}$ Supilo F., uvodni programski članak u renoviranom Novom listu, broj 1, 1904.

${ }^{40}$ A. Goluhovski (1849.-1921.), austrougarski ministar spoljnih poslova početkom XX veka se žalio da "ima najveću brigu, da bi u slučaju kakve konflagracije na Balkanu Južna Dalmacija mogla činiti središte antiaustrijskog pokreta" (Erzherzog Franz Ferdinands Wirken und Wollen, Berlin, 1929, 170).
} 
Dalmatinski pravaši su na početku XX veka od 1900. do 1902. formalno isticali da ne odbacuju u principu ideju o slozi sa dalmatinskim Srbima pa čak ni sa Italijanima, ali samo "u radu za narodno jedinstvo, za narodnu slobodu. Narodno pak znači u nas hrvatsko". ${ }^{41}$ Međutim, većina Srba iz čitave Trojednice je u ovakvim uslovima saradnje videla prikrivenu politiku pohrvaćivanja Srba shodno staroj pravaškoj ideologiji da na prostoru Trojednice živi samo "hrvatski politički narod" koji govori i piše hrvatskim jezikom. ${ }^{42}$ Dakle, još na početku XX veka dalmatinski pravaši su ponavljali staru misao koju je formulisao još 1868. Mihovil Pavlinović u svom govoru prilikom otvaranja Čitaonice u Jelsi na Hvaru, a tu misao će u najglavnijim crtama ponoviti i Josip Smodlaka u saborskom govoru $1902 .{ }^{43}$ Pravaški Narodni list je tvrdio da srpski političari u Dalmaciji ne bi smeli voditi drugačiju politiku od one koju vode predstavnici hrvatskih političkih partija prvenstveno zbog toga što Srbi sa Hrvatima čine isti narod shodno romantičarskoj teoriji da istovetnost jezika ujedno predstavlja i identičnost narodnosti. Ali upravo zato što je bila reč o jednom narodu koji je govorio istim jezikom, dalmatinski Srbi su za Narodni list predstavljali pravoslavne Hrvate između ostalog i stoga što je Dalmacija svojatana kao ekskluzivno hrvatska teritorija na osnovu hrvatskog "povijesnog" prava. ${ }^{44}$ Slične stavove je izneo i Josip Smodlaka u spomenutom govoru 1902. kada je tvrdio da sem Srba u Dalmaciji nema ni Italijana kao posebne nacionalnosti. Za pravaše nije bilo u Dalmaciji niti pravog srpskog, niti pravog italijanskog, nacionalnog elementa. ${ }^{45}$ Međutim, bitno je napomenuti da je stav dalmatinskih pravaša prema Srbima i Italijanima bio različit. Protiv Italijana i njihove "Talijansko-autonomaške" stranke pravaši su se borili veoma oštro, dok su prema Srbima imali suzdržljiviji stav. Razlog za takvu politiku je bio taj što su po pravaškoj ideologiji Srbi na osnovu istovetnog jezika sa Hrvatima smatrani pripadnicima hrvatske nacije. Iz ovih razloga su Srbi iz Dalmacije okupljeni oko Srpske narodne stranke na Primorju ${ }^{46}$ strahovali da bi u slučaju ujedinjenja dalmatinskih pravaša i narodnjaka u jedinstvenu Hrvatsku stranku u njoj preovladala pravaška ideologija. ${ }^{47}$

\footnotetext{
${ }^{41}$ Narodni list, 58/28. 7. 1900., "Misao hrvatskog jedinstva".

${ }^{42}$ Od vremena hrvatskog nacionalnog preporoda - "Ilirskog pokreta" - (1835.-1849.) književni jezik Hrvata je ustvari postao srpski narodni govor koga je Vuk Stefanović Karadžić standardizovao kao književni jezik Srba (Milosavljević P., Srbi i njihov jezik. Hrestomatija, Priština, 1997, 13-50). Tu činjenicu je još 1846. potvrdio sam Ljudevit Gaj u svom članku “Čije je kolo?” koji je štampan u № 31. od 1. avgusta u Danici napisavši: "Ta n.p. sav svet znade i priznaje, da smo mi (hrvatski ilirci, primedba V. B. S.) književnost ilirsku podigli i uveli; nu nama ni izdaleka nije na um palo ikada tvàrditi, da to nije sèrbski već ilirski jezik; pače ponosimo se i hvalimo Bogu Velikomu, što mi Hèrvati s bratjom Sèrbljima sada jedan književni jezik imamo". Očito je da je književni jezik Hrvata koji su prihvatile vođe "llirskog pokreta" kako za Vuka tako i za Lj. Gaja bio srpski, ali je već za Vatroslava Jagića književni jezik Hrvata bio hrvatskosrpski da bi krajem XX veka taj jezik bio nazivan od strane Hrvata samo kao hrvatski književni jezik.

${ }^{43}$ Pavlinović M., "Hrvatstvo, srpstvo, slovinstvo", Pjesme i besjede, Zadar, 1873, 269; Brzopisna izvješća Pokrajinskoga sabora dalmatinskoga, 1902, Smodlaka, 878.

${ }^{44}$ Narodni list, 98/28. 11. 1900., "Izborni kompromis"; Isto, 15/20. 2. 1901., "Borba sa Hrvatima".

${ }^{45}$ Crvena Hrvatska, 27./7. 7. 1900.; Brzopisna izvješća Pokrajinskoga sabora dalmatinskoga, 1902, Smodlaka, 877-885.

${ }^{46}$ Srpska narodna stranka na Primorju je osnovana 1880. od strane onih dalmatinskih Srba koji su se prethodne godine odvojili od (hrvatske) Narodne stranke usled antisrpske politike narodnjaka na koju je u Saboru jasno upozorio Stefan Mitrov Ljubiša 1877. (Tihomir Rajčić, "Politički nacionalni aspekti fenomena 'zemljaštva' u Dalmaciji (1873.-1878.)", Radovi Zavoda za povijesne znanosti HAZU u Zadru, br. 56, 2014, 213. U netolerantnosti prema Srbima i srpskom pitanju u Trojednici se naročito isticao jedan od najuticajnijih prvaka Narodne stranke - Mihovil Pavlinović, koji je optuživao Ljubišu da je bečki agent dok je vođstvo narodnjaka imalo stav
} 
Među dalmatinskim Srbima koji su najviše upozoravali na mogućnost dominacije pravaške ideologije u slučaju pravaško-narodnjačke koalicije su se naročito isticali oni koji su pripadali tzv. "krugu Srba katolika" okupljenih oko rimokatoličkog Srbina Antuna Fabrisa, urednika novina Dubrovnik i književnog lista Srđ i potpredsednika Srpske čitaonice Strmica. Ova grupa Srba katolika je u potpunosti prihvatila lingvističku formulu o nacionalnoj determinaciji Vuka Stefanovića Karadžića na osnovu koje su svi Južni Sloveni kojima je štokavski dijalekt maternji jezik faktički bili etnički Srbi bez obzira na verske ili regionalne razlike među njima. Oni su održavali intenzivne veze sa svim srpskim zemljama i jačali ideju zbližavanja svih južnoslovenskih štokavaca pod srpskim nacionalnim imenom i njihovim političkim ujedinjenjem u jednu nacionalnu državu. Taj program je jasno naznačen u prvom broju Fabrisovog Srđa, koji je izlazio od 1902. do 1908., a u kome je stajalo da list propagira "misao srpskog književnog jedinstva na osnovu zdravoga razvitka narodnih sila, koje je naš besmrtni Vuk na vidik iznio i objavio". Svakako se ovde radi o Vukovom mišljenju da su svi štokavci Srbi. ${ }^{48}$ Fabrisove ideje o stvaranju jedinstvene nacionalne države Srba na lingvističkim ideološkim osnovama štampane u Dubrovniku podržavao je naročito Luko Zore u svojim literarnim radovima publikovanim u Srđu. U takvom ujedinjenom "štokavskom" srpskom carstvu (t.j. srpskom lingvističkom komonveltu ili Štokaviji) bi se našle pored Bosne i Hercegovine i Dalmacija sa Dubrovnikom. ${ }^{49}$

Borbu za Srpstvo Dubrovnika ("srpska Firenca") je A. Fabris naglasio otvoreno u novogodišnjem uvodniku u listu Dubrovnik za 1901. Ta borba je trebala da se vodi na ideološkim osnovama Vukove štokavske teorije Srpsva i činjenice da su Dubrovčani oduvek govorili i pisali (od XV veka) štokavskim dijalektom. Stoga je Fabris pisao: "Zajednica jezika, karvi i interesa grada Dubrovnika sa srpskijem narodom osveštena je prošlošću... Što srpski narod, u čiju sferu interesa grad Dubrovnik spada, bude moćniji i sretniji, to će i budućnost Dubrovnika biti sjajnija". Dakle, "zajednica sa srpskim narodom" na osnovu istovetnosti jezika i kulturne baštine nastale na njemu treba da bude prirodna težnja Dubrovčana i sudbina samoga grada. ${ }^{50}$ Grupa rimokatoličkih Srba iz Dalmacije okupljena oko A. Fabrisa je odbacivala ideologiju srpskih crkvenih krugova, koju je u Dalmaciji zastupao episkop Milaš, da se pojam Srpstva isključivo vezivao za pravoslavlje ističući da je jezik primarniji nacionalni identifikator od veroispovesti. Zato su za njih postojali "Srbi tri verozakona". Sa ovakvih ideoloških pozicija dubrovački Dubrovnik napada onaj deo uredništva zadarskog Srpskog glasa koji je bio pod znatnim uticajem srpskih crkvenih krugova u Dalmaciji a koji su se plašili uplitanja Srba rimo katolika u rešavanje srpskih nacionalnih interesa. ${ }^{51}$ To se pre svega odnosilo na Vujanović-Milaševu grupu koja je priznavala Hrvate za poseban narod stojeći na stanovištu da su samo pravoslavci Srbi, a da su katolici (rimokatolici i unijati) Hrvati.

\footnotetext{
da Srbi u Dalmaciji vode antihrvatsku i proaustrijsku politiku (Rade Petrović, Nacionalno pitanje u Dalmaciji u XIX. stoljeću, Sarajevo-Zagreb, 1982, 270-283).

${ }^{47}$ Dubrovnik, 27/7. 7. 1901.; Isto, 43/27. 10. 1901.

${ }^{48}$ Barić H., Izabrani članci Antuna Fabrisa, Beograd, 1940.

${ }^{49}$ Dubrovnik, 26/29. 6. 1901. i drugi brojevi; Kulišić F., "Pogled na Zorin književni rad i politiku", Srđ, 16/31. 12. 1906. Pored A. Fabrisa i prof. Zore, od pripadnika "kruga Srba katolika" treba istaći i Luku Verona, dr. Antona Pugliesia, Hermanegilda Joba, Đuru Vojnovića, Antuna Pašarića, Ivu Miškovića i Mihu Vacetija (Vacchetti).

${ }^{50}$ Dubrovnik, 1/1901.

${ }^{51}$ Srpski glas, 2/11. 1. 1901., "Novi juriš - stara petljanija".
} 
Fabrisov Dubrovnik je naročito zazirao of Frane Supila zbog njegovog delovanja na širenju hrvatske nacionalne svesti u dubrovačkoj regiji preko Crvene Hrvatske jednim delom na sličnim ideološkim osnovama, tj. tvrdeći da je dubrovačka štokavština dokaz da stanovnici grada Dubrovnika pripadaju hrvatskoj naciji. ${ }^{52}$ Stoga su pripadnici "kruga Srba katolika" odbacivali svaku pomisao na saradnju sa svim onim hrvatskim političarima koji su se borili za sjedinjenje Dalmacije ili Bosne i Hercegovine sa Hrvatskom-Slavonijom. Prihvatanje takve saradnje bi se kosilo sa osnovnim ideološkim principima ovog kruga prema kojima je jezik stanovništva kako Dalmacije sa Dubrovnikom tako i Bosne sa Hercegovinom bio isti onaj kojim su govorili stanovnici Kraljevine Srbije, t.j. štokavski dijalekt. Dakle, na osnovu Vukovog lingvističkog modela nacionalnog određenja Južnih Slovena zahtevalo se ujedinjenje Dalmacije i Bosne i Hercegovine sa maticom Srbijom. Može se zaključiti da je za ovu grupu predstavnika srpske politike u Dalmaciji Hrvatsvo bilo politički a ne nacionalni fenomen. Ono je bilo tvorevina austrijskih vladajućih krugova potpomognutih katoličkom crkvom s ciljem da se razbije iz čisto političkih razloga etnojezičko jedinstvo Srpstva na čitavom Balkanu pretvaranjem katoličkih etničkih Srba štokavaca u štokavske političke Hrvate. Hrvatska nacionalna misao - isticao je Dubrovnik - bila je vrlo pogodno sredstvo da se težnje za germansko-austrijskom dominacijom na Balkanu prikriju ispod maske Hrvatstva, pa je stoga Hrvatstvo bilo prirodni saveznik Nemstvu. ${ }^{53}$ Za Fabrisove pristalice, Hrvatsvo je bilo samo geografski pojam uglavnom vezivan za teritoriju "uže Hrvatske" (t.j. kajkavske Hrvatske oko Zagreba, Varaždina i Karlovca) a ne nacionalni pojam: Hrvati su bili pleme ali ne i nacija. Nacionalni pojam je po njima bio daleko širi i temeljio se na srpskoj narodnosti koja je obuhvatala sve štokavce.

Ipak, nisu samo Srbi rimokatolici dubrovačko-bokokotorske regije zastupali među dalmatinskim Srbima ideju "štokavskog Srpstva". To je isto činila jaka grupa severnodalmatinskih Srba sa centrom u Zadru okupljena oko onog dela rukovodstva Srpske narodne stranke na Primorju i uredništva zadarskog Srpskog glasa koje se protivilo "pravoslavnom ekskluzivizmu Srpstva" srpske pravoslavne crkvene hijerarhije. Oni su takođe smatrali kao i njihovi južnodalmatinski istomišljenici da vera nije i ne sme biti nikakvo merilo nacionalnog određenja (tj. razdvajanja), a postojeće jezičke razlike nisu bile suštinske već dijalektološke prirode. Ono što je sve Južne Slovene štokavce ujedinjavalo u jednu jedinstvenu i nedeljivu nacionalnu zajednicu koja je imala jedan zajednički interes bilo je srpsko nacionalno ime i srpski jezik. Na osnovu ovakve ideologije etnolingvističke determinacije, Srpski glas je tvrdio: "Istorijska je laž i izvrtanje, kada pisac hrvatsko pleme, koje je dio srpskog naroda, hoće da uzdigne na stupanj naroda, a srpski narod da snizi na stupanj plemena tobožnjeg hrvatskog naroda. Srpski narod ima sve one osobine, koje daju jednom narodu biljeg narodnosti: on je iz sebe razvio srpski narodni jezik, on je očuvao narodni život i običaje, on je sam po sebi osnovao i razvio političku slobodu. Naprotiv, hrvatsko pleme nije razvilo svog plemenskog narječja, nije očuvalo narodnih običaja, već bi se bilo izgubilo u moru tuđinštine, da nije stalo primati životni sok narodnosti od srpskog naroda. Hrvatsko je pleme primilo srpski jezik, pjesme, mnoge običaje i tijem i srpsko obilježje. Ono je stoga za uvijek pripojeno srpskom tijelu. To je bila povijesnička

\footnotetext{
${ }^{52}$ Dubrovnik, 7/16. 3. 1902.

${ }^{53}$ Dubrovnik, 7/17. 2. 1901.; Isto, 8/24. 8. 1901; Srpski glas, 45/8. 11. 1901., "Preokret" I.
} 
Iskustva i pouke iz prošlosti

neophodnost..." ${ }^{54}$ Iz svega ovoga proizlazi zaključak da je teritorija Hrvatske na kojoj se govorilo štokavskim dijalektom srpska zemlja. Za razliku od Dubrovnika, Srpski glas je dopuštao mogućnost da se Hrvatstvo u Dalmaciji moglo razviti u narodnost ali se to u stvarnosti nije dogodilo prvenstveno stoga što Hrvati nisu uspeli da formiraju u XIX veku svoj posebni književni nacionalni jezik. Stoga je Hrvatstvo bilo prolazna zabluda stvorena "zahvaljujući austrijskim vladama".

Treba istaći da su se slični stavovi u odnosu na hrvatske (t.j. hrvaćanske) Srbe mogli naći i na hrvatskoj strani u čitavoj Trojednici pa i u Dalmaciji. Nisu samo hrvatski pravaši već i hrvatski narodnjaci tvrdili da u Dalmaciji ne žive Srbi u nacionalnom smislu, tj. da se tu radilo o pravoslavnim Hrvatima. Slično kao i u prethodnom slučaju, štokavski dijalekt (t.j. narečje) je proglašen hrvatskim nacionalnim jezikom pa je shodno formuli romantičarskog lingvističkog nacionalizma spočetka XIX veka smatrano da svi pripadnici istog jezika pripadaju istovremeno i istoj etnonaciji. To je u ovom konkretnom slučaju značilo da su štokavski Srbi samo pleme hrvatske nacije ili species hrvatskog genus-a.

Na drugoj strani, osnovni razlog za nepopustljivost dalmatinskih pravaša prema domaćim Italijanima leži u činjenici da se veoma jaka italijanska iredentistička propaganda širila Dalmacijom upravo preko dalmatinskih Italijana. ${ }^{56} \mathrm{U}$ toj propagandi je društvo "Dante Alighieri" imalo vodeću ulogu brinući se prvenstveno da se neguje italijanska kultura i jezik kako bi se očuvala italijanska nacija u Dalmaciji i Istri ali i "italijanski karakter" ove dve provincije. Predsednik ovog društva P. Vilari je tvrdio da su obe ove pokrajine italijanske, naseljene odvajkada Italijanima jer se i u Dalmaciji i u Istri pretežno govorilo vekovima italijanskim jezikom. ${ }^{57}$ Društvo "Lega Nazionale" se prevashodno brinulo o funkcionisanju italijanskih škola u Dalmaciji u kojima je glavni predmet izučavanja bio italijanski jezik i književnost kao i o italijanskim čitaonicama u većim gradovima kao što je to bila "Gabinetto di lettura" u Splitu. Dalmatinski Italijani su svoje nacionalne zahteve jasno izložili na zasedanju Dalmatinskog sabora 1902. kada je italijanski zastupnik, dugogodišnji gradonačelnik Zadra i vođa Italijanske (autonomaške) stranke, Luiđi Zilioto u kratkim crtama predstavio glavni kurs delovanja svoje stranke u Dalmaciji: 1) priznavanje pune ravnopravnosti italijanskog jezika sa hrvatskim jezikom, 2) otvaranje u svim gradovima Dalmacije italijanskih škola, 3) obezbeđivanje Italijanima veći broj radnih mesta u upravnim, sudskim i drugim državnim službama i 3) prestanak progona Italijana od strane vlasti. ${ }^{5 \hat{\delta}}$ Dakle, ono što je Italijanska stranka u Dalmaciji zahtevala bilo je priznavanje nacionalnog identiteta Italijana prevashodno putem otvaranja škola na italijanskom jeziku, davanje italijanskom jeziku statusa državnog jezika uporedo sa hrvatskim i poboljšanje radnih uslova za italijansku naciju.

\footnotetext{
${ }^{54}$ Srpski glas, 43/25. 10. 1901., "Poziv Dalmacije II".

${ }^{55}$ Isto; Srpski glas, 52/27. 12. 1901, "Državni rezon".

${ }^{56}$ Delich S., L'irrendentismo italiano in Dalmazia. Secondo i documenti segreti della polizia austriaca, Roma, 1924.

${ }^{57}$ Italijanski karakter Istre i Dalmacije je decidno pobijao još početkom XVI veka Hvaranin Vinko Pribojević u svom čuvenom govoru iz 1525. De origine successibusque Slavorum koji je 1535. štampan u Veneciji (videti savremeno izdanje: Pribojević V., De origine successibusque Slavorum, Zagreb, 1951). Pribojević je tvrdio da se na osnovu jezika, lokalnih govora, običaja i geografskog položaja može sa sigurnošću tvrditi da su Dalmacija i Istra čisto slovenske zemlje. O slovensko-romanskoj etnosimbiozi u Dalmaciji u srednjem veku videti u: Novak V., "The Slavonic-Latin Symbiosis in Dalmatia During the Middle Ages", Slavonic and East European Review, XXXII, № 78, 1953, 1-28.

${ }^{58}$ Brzopisna izvješća Pokrajinskoga sabora dalmatinskoga, 1902, Ziliotto, 842-845.
} 
Glavna teza Italijana u Dalmaciji je bila da nacionalnost označavaju jezik i kultura koja je odraz tog istog jezika, kao i da se nacionalni karakter jedne oblasti prevashodno određuje prema obrazovnom profilu njene inteligencije. Dakle, pitanje kulturne pripadnosti dalmatinske inteligencije je bio kamen temeljac političke ideologije Italijanske (autonomaške) stranke. U to vreme, dalmatinska inteligencija je bila pretežno obrazovana na italijanskim univerzitetima. Razlog ovoj činjenici je bila austrijska školska politika prema kojoj diploma Zagrebačkog sveučilišta nije bila priznata na teritoriji Cislajtanije bez prethodnog polaganja diferencijalnih ispita na jednom od austrijskih univerziteta. To je za dalmatinske studente nesumljivo bila velika prepreka usled neznanja nemačkog jezika kojim se nije nikada govorilo u Dalmaciji, a kojeg lokalno stanovništvo iz političkih razloga nije ni htelo da uči. Stoga su dalmatinski studenti bili upućeni na italijanske univerzitete čije su diplome bile u potpunosti priznate od strane bečkih vlasti. Na taj način su diplome sa italijanskih univerziteta i poznavanje italijanskog jezika od strane dalmatinske inteligencije bili ključni argumenti Italijanskoj stranci da tvrdi da je čitava Dalmacija italijanska po romantičarskoj formuli da se nacionalna pripadnost određuje prevashodno putem jezičke pripadnosti. Stoga je najekstremnije krilo Italijanske stranke zahtevalo da se italijanski jezik proglasi za jedini službeni jezik u Dalmaciji, t.j. da mu se povrati status koji je uživao sve do sredine XIX veka kada je hrvatski jezik u zvaničnoj korespondenciji i opštenju sa vlastima izjednačen sa italijanskim. Italijanski ekstremisti su ovakve svoje zahteve objašnjavali "činjenicom" da su Italijani odvajkada bili većinsko stanovništvo u Dalmaciji. Za njih je bečka vlada pod čijom se upravom nalazila Dalmacija još od 1797./1814. proglašenjem hrvatskog jezika za zvanični jezik u Dalmaciji smišljeno vodila politiku denacionalizacije i kroatizacije italijanske većine u ovoj provinciji. ${ }^{59}$ Ovakvom ideološkom pristupu u određivanju nacionalne pripadnosti su se naročito suprotstavljali hrvatski predstavnici u Saboru. Tako je Pero Čingrija isticao da su kultura i nacionalna pripadnost dve različite kategorije i da je tvrdnja "kako čovjek pripada onoj narodnosti u čijoj je književnosti izobražen. ...nesmisao". ${ }^{\circ}$

Posebno političko krilo u Italijanskoj stranci je činila grupa političara koji su sebe nazivali "dalmatinskim autonomašima", okupljenih oko ideje dalmatinizma. Oni su politiku iredentizma odbacivali zarad dalmatinskog autonomizma čije je ideološke osnove zastupao njihov list Pravi Dalmatinac, koji se pojavio 1897. ali se nakon Riječke i Zadarske rezolucije ubrzo ugasio. Prema pisanju tog lista, suština dalmatinizma jeste u tome da on predstavlja sintezu svega što je dalmatinsko i nije povezan ni sa kakvim posebnim italijanskim, hrvatskim ili srpskim nacionalno-ideološkim obeležjima i karakteristikama. Shodno tome, jezik Dalmatinaca nije ni italijanski, ni hrvatski niti srpski već je to naš jezik ili naški. Međutim, "dalmatinski autonomaši" su prikazivali italijansku kulturu kao izvornu i pravu kulturu Dalmacije pa su stoga preporučivali izučavanje italijanskog jezika. Njihov zadatak je bio "pobratimiti - kao u ljepim prošlim vremenima - one što govore talijanski s onima što govore naški, pod starim i časnim barjakom autonomije". ${ }^{61}$

\footnotetext{
${ }^{59}$ Prema popisu dalmatinskog stanovništva iz 1900. u ovoj provinciji je od ukupno 593,783 stanovnika bilo 15,279 Italijana (Foretić D., "O etničkom sastavu stanovništva Dalmacije u XIX st. s posebnim osvrtom na stanovništvo talijanske narodnosti”, Dalmacija 1870, Zadar, 1972, 77). Najveći broj italijanskog stanovništva u Dalmaciji je bio 1880. kada in je bilo 27,305 od ukupno 476,101 stanovnika Dalmacije. Najveća koncentracija italijanskog stanovništva u Dalmaciji je bila u gradu Zadru.

${ }^{60}$ Brzopisna izvješća Pokrajinskoga sabora dalmatinskoga, 1901., Čingrija, 650-653; Isto, Biankini, stranica 738; Isto, 1903.

${ }^{61}$ Pravi Dalmatinac, broj 1/24. 1. 1904.
} 
Iskustva i pouke iz prošlosti

Pripadnici Srpske narodne stranke na Primorju su ostajali hladni na italijanske nacionalne zahteve jer se u njima nije zahtevala ravnopravnost italijanskog jezika sa hrvatsko-srpskim već samo sa hrvatskim iz čega su izvodili zaključak da za italijanske političke prvake srpska nacija nije ni živela na prostoru Dalmacije. Iste primedbe su srpski narodnjaci iz Dalmacije upućivali i svim onim hrvatskim političarima koji su se zalagali za hrvatski a ne hrvatsko-srpski jezik u Dalmaciji. Tako su na Dalmatinskom saboru iz 1902. srpski poslanici kritikovali predlog jezičke reforme u državnim upravnim organima carskog namesnika u Dalmaciji Handela prema kojoj se hrvatski jezik favorizovao na štetu italijanskog, srpski jezik nije ni spominjao a nemački jezik polako uvodio u službenu upotrebu radi lakšeg komuniciranja Dalmacije sa administrativnim centrom države u Beču. Ovaj pokušaj uvođenja nemačkog jezika kao službenog u Dalmaciji "samo s obzirom na potrebe kod ministarstva u Beču" "̋2 je izazvao burna negodovanja i hrvatskih i italijanskih saborskih poslanika a naročito Anta Trumbića. Svi poslanici su dokazivali da Dalmacija nema nikakvih potreba za uvođenjem nemačkog jezika kao zvaničnog pa je stoga Sabor jednoglasno odbio ovaj Handelov predlog. Handelov neuspeh da zakonskim putem preko Sabora uvede nemački jezik u Dalmaciju nije ga obeshrabrio da nemački jezik uvede kroz praksu u službenu upotrebu u nekim većim dalmatinskim gradovima. Bio je to slučaj na prvom mestu sa poštanskom službom, prizivnim sudom u Zadru, finansijskim kancelarijama pa čak i sa školskim sistemom. ${ }^{63}$

U favorizovanju nemačkog jezika u administrativnim službama Dalmacije se vidi jasna tendencija bečke vlade da pojača državni centralizam ali i da poveća broj pripadnika nemačke nacionalnosti u ovoj provinciji. Obzirom da među domaćim činovničkim aparatom nije faktički bilo nikoga ko bi u zadovoljavajućoj meri vladao nemačkim pisanim i govornim jezikom davalo je centralnoj vladi dobro opravdanje da uvođenjem nemačkog jezika ujedno postavlja na rukovodeća mesta ljude nemačke nacionalnosti. Nacionalno-politička podeljenost stanovništva Dalmacije se može najbolje uočiti na pitanju jezika pred kojim se našao odbor sedmorice Dalmatinskog sabora te 1902. sastavljajući adresu caru. Naime, pri glasanju u Saboru o saborskoj adresi caru, italijanski i srpski poslanici nisu podržali hrvatski predlog o jeziku po kome bi se hrvatski jezik proglasio zvaničnim kao i predlog o sjedinjenju Dalmacije sa Hrvatskom i Slavonijom. Kao što su italijanski poslanici tražili da se italijanski jezik pored hrvatskog ozakoni zvaničnim jezikom pokrajine, tako su isti status za srpski jezik tražili i srpski poslanici. U oba slučaja razlog je bio iste prirode: priznavanjem postojanja nacionalnog jezika bi se ujedno automatski priznala i egzistencija same te nacije u Dalmaciji koja tim jezikom govori kao maternjim.

\section{Pitanje jezika u politici „novog kursa“ u Dalmaciji}

Prvi znaci preokreta u hrvatsko-srpskim odnosima u Dalmaciji se mogu uočiti na zasedanju Dalmatinskog sabora 1902. kada su i Hrvatska narodna stranka i Hrvatska stranka prava pokazale prve znake želje i spremnosti da sarađuju sa Srpskom narodnom strankom na Primorju. U to vreme je ideologija pravaša evoluirala od negacije postojanja Srba i srpskoj jezika i pisma u Dalmaciji do priznavanja postojanja posebnog srpskog nacionalnog

\footnotetext{
${ }^{62}$ Brzopisna izvješća Pokrajinskoga sabora dalmatinskoga, 1902, Handel, 269.

${ }^{63}$ Isto, Nardelli, 1095.
} 
entiteta i zajedničkog hrvatsko-srpskog jezika kao jezika dva srodna naroda, što je stvorilo povoljne uslove na srpskoj strani za zajednički nacionalno-politički rad sa hrvatskim strankama u Dalmaciji. Za uzvrat, od dalmatinskih Srba se očekivalo da odustanu od negiranja hrvatskog karaktera Dalmacije i da priznaju važnost hrvatskog državnog prava za Dalmaciju. $^{64}$ Tako je pravaš Josip Smodlaka istakao želju da prihvati "pravedne želje" dalmatinskih Srba pa i Italijana ukoliko su one u skladu sa "opštim interesom sve naše zemlje i naroda". Tu želju Smodlaka je ponovio i 1903. u svom govoru u Šibeniku. ${ }^{65}$ lako je Smodlaka priznavao Srbima iz Dalmacije pravo na poseban jezik, pismo i veru, odbio je da prizna postojanje posebne srpske nacionalnosti što su predstavnici Srpske narodne stranke na Primorju shvatili kao neiskrenu ponudu saradnje jer je i dalje iza maske pomirenja lebdela velikohrvatska ideja o Hrvatstvu sva tri dijalekta: štokavskog, kajkavskog i čakavskog (tzv. dijalekatska trihotomija hrvatskog nacionalnog korpusa). ${ }^{66}$ Beogradski list Svetovid je tim povodom pisao da "domaći" (t.j. Srbi u Dalmaciji, primedba V. B. S.) ne mogu promeniti svoje nacionalno ime i jezik jer imaju "gosta" (tj. Hrvate, primedba V. B. S.) u kući. K. Kovačević iz Srpske narodne stranke na Primorju je za saborskom govornicom prokomentarisao spomenuti Smodlakin predlog da pod tim uslovima "...do sloge između Hrvata i Srba neće doći" s obzirom da bi to dovelo do "naše (srpske, primedba V. B. S.) narodne smrti". ${ }^{67}$ Po njemu je u Dalmaciji živeo ogroman broj etnolingvističkih Srba, očigledno aludirajući na štokavsku teoriju "lingvističkog Srpstva", dok je, smatrao je Kovačević, samo iz političke nezrelosti i nedovoljno razvijene nacionalne svesti dalmatinsko stanovništvo podleglo pohrvaćivanju. Dubrovnik je tvrdio da se iza Smodlakinog poziva na saradnju krio zahtev da se Srbi pretvore u "politickije Hrvate". Ovaj list nije prihvatio ni Smodlakin predlog da se jezik Južnih Slovena u Dalmaciji nazove dvočlanim imenom jer "narod vaskolik posvjedočio je svoje jedinstvo u jeziku jednom, od Trsta do Soluna". Očigledno je da su za Dubrovnik štokavski Srbi naseljavali čitavu teritoriju Balkana od Istre do severne Grčke. ${ }^{68}$ Odreći se svog nacionalnog jezika prihvatanjem dvočlanog naziva za jezik značilo je prepustiti Hrvatima srpske zemlje. ${ }^{69}$ Ipak je Smodlaka u svom govoru ostavio prostora da se južnoslovenski element u Dalmaciji nazove dvočlanim imenom - hrvatsko-srpskim, kao i njegov jezik, ukoliko bi dalmatinski Srbi odustali od srpske državne ideje u Dalmaciji. ${ }^{70}$ Prema tome, mogućnost za "dualizam imena" naroda i jezika je ostavljena otvorenom. ${ }^{11} \mathrm{U}$ isto vreme, Smodlaka je priznavao onim stanovnicima Dalmacije koji su sebe nazivali Italijanima pravo da neguju italijanski jezik ali je odlučno odbio svaku pomisao da italijanski jezik bude ravnopravan sa hrvatskim iz razloga jer nije priznavao postojanje italijanske nacije u Dalmaciji. Po njemu se tu radilo o italijaniziranim Slovenima koji ako neće da budu etnički Hrvati mogu da se dekla-

\footnotetext{
${ }^{64}$ Lovrenčić R., Geneza politike novog kursa u Hrvatskoj, Zagreb, 1965, 126-128; Dubrovnik, 30/28. 7. 1901.

${ }^{65}$ Smodlaka J., Govor o organizaciji hrvatske stranke u Dalmaciji (13. 4. 1903.), Rijeka, 1903.

${ }^{66}$ Brzopisna izvješća Pokrajinskoga sabora dalmatinskoga, 1902, Smodlaka, 877-878. Inače, skoro je nemoguće da je dijalekatska trihotomija hrvatske nacije nastala isključivo na čistoj hrvatskoj narodnosnoj osnovi.

${ }^{67}$ Brzopisna izvješća Pokrajinskoga sabora dalmatinskoga, 1902, Kovačević, 889.

${ }^{68}$ Dubrovnik, 31/3. 8. 1902, "Govor g. d. ra Smodlake"; Isto, 33/17. 8. 1902., "Bez vas, ili preko vas"; Isto, 34/24. 8. 1902., "Pismo iz Zadra; Isto, 35/31. 8. 1902., "Srbi i Hrvati".

${ }^{69}$ Isto.

${ }^{70}$ Brzopisna izvješća Pokrajinskoga sabora dalmatinskoga, 1902, Smodlaka, 877-878.

${ }^{71}$ Tu ideju je zastupao i Mihovil Pavlinović (Pavlinović M., "Hrvatstvo, srpstvo, slovinstvo", Pjesme i besjede, Zadar, 1873, 269).
} 
Iskustva i pouke iz prošlosti

rišu samo kao "Dalmatinci" ali nikako kao etnički Italijani. ${ }^{72}$ Dakle, u ovom slučaju Smodlaka nije priznavao funkcionisanje osnovnog principa lingvističkog nacionalizma, koji je inače primenjivao u slučaju štokavskih Srba u Dalmaciji, t.j. da maternji jezik određuje nacionalnu pripadnost. Slične poglede na nacionalno pitanje u Dalmaciji su imali i neki drugi hrvatskodalmatinski političari i stranački ideolozi kao Pero Čingrija, vođa dalmatinskih narodnjaka, i Juraj Biankini koji se ideološki nalazio između narodnjaka i pravaša. ${ }^{73}$

Jedan od najbitnijih elemenata politike "novog kursa" kako u Hrvatskoj-Slavoniji tako i u Dalmaciji bilo je političko-programsko jedinstvo hrvatskih stranaka. Ideološki temelj ovakve političke fuzije je predstavljao zahtev da cilj narodne borbe mora biti "da se Hrvatska povrati Hrvatima, da Hrvat bude svoj na svome" i da to bude zajednička briga svih ujedinjenih hrvatskih političkih snaga u Dalmaciji. ${ }^{74}$ Trebalo je stvoriti jedan što masovniji narodni front koji bi ličio na narodnu vojsku u cilju preporoda celokupnog narodnog života. ${ }^{75}$ Hrvatski političari "novog kursa", a prvenstveno njegove vođe A. Trumbić i Frano Supilo, su bili svesni da se za uspešan rad pored ujedinjenja svih hrvatskih političkih snaga Dalmacije mora postići sporazum kako sa dalmatinskim Italijanima tako i sa dalmatinskim Srbima. Tako do promene u odnosima hrvatsko-italijanske politike u Dalmaciji dolazi sredinom 1903. iz dva razloga: 1) zbog želje Italijana da usled teške ekonomske situacije u Dalmaciji prihvate saradnju sa hrvatskim političkim strankama i 2) zbog nastojanja hrvatskih prvaka da zadovolje neke od italijanskih zahteva kako bi se pronašao modus vivendi i prevazišla međunacionalna zategnutost.

Pojedini hrvatski predstavnici su predlagali da se Italijanima prepusti Trst i zapadna Istra da bi se uklonili međusobni sukobi. Takođe, smatralo se da je sporazum sa Italijanskom strankom conditio sine qua non za politički sporazum sa dalmatinskim Srbima. Ipak, verovalo se da će put do hrvatsko-italijanskog sporazuma biti znatno lakši od sporazuma Hrvata sa Srbima. ${ }^{76}$ Ipak, ispostavilo se da su pregovori sa Italijanima, naročito oni koji su vođeni u Zadru, bili dosta teški pa do sporazuma u tom trenutku nije ni došlo. Italijanski zahtevi (jezik, broj italijanskih škola, zastupljenost Italijana u mesnim upravama, broj saborskih mesta, zastupljenost italijanskog jezika u uredima i kao nastavni predmet u svim dalmatinskim i istarskim školama) su se pokazali kao neprihvatljivi u celini za hrvatsku stranu koja je naročito prema pitanju jezika bila veoma skeptična i nepopustljiva. ${ }^{77}$ Naročito se sa hrvatske strane potenciralo da se italijanski jezik ne izučava u svim dalmatinsko-istarskim školama već samo u onim namenjenim italijanskoj manjini kao njihov maternji jezik.

U leto 1903. hrvatske stranke sledbenice politike "novog kursa" su sem sa dalmatinskim Italijanima vodile intenzivne pregovore i sa dalmatinskim Srbima. Prilike za postizanje hrvatsko-srpskog sporazuma u Dalmaciji su nakon Majskog prevrata (29. maj/11. jun 1903.) u Srbiji i zbacivanja dinastije Obrenovića izgledali povoljniji nego ikad ranije. Ipak, za uspešan ishod

\footnotetext{
${ }^{72}$ Brzopisna izvješća Pokrajinskoga sabora dalmatinskoga, 1902, Smodlaka, 881-882.

${ }^{73}$ Isto, Čingrija, 905-906; Isto, Biankini, 362.

${ }^{74}$ Smodlaka J., Govor o organizaciji hrvatske stranke u Dalmaciji (13. 4. 1903.), Rijeka, 1903.; Znanstvena knjižnica u Splitu, Arhiv Ante Trumbića, M 405, 37; Isto, "Pismo M. Marjanovića A. Trumbiću, 27. 6. 1903.", M 402, 13.

${ }^{75}$ Crvena Hrvatska, 24/13. 6. 1903., "Pred velikom odgovornosti"; Novi list, 1/1904.

76 Jedinstvo, leto 1903., članak Natko Nodila "Mi i Talijani”; Nase Jedinstvo, 61/21. 11. 1905; Marjanović M., Hrvati i Talijani, Dubrovnik, 1904, 17.

${ }^{77}$ O tome videti: Šepić D., "Jugoslavenski pokret i Milan Marjanović 1901-1919", Zbornik Historijskog instituta JAZU, 3, Zagreb, 1960.
} 
pregovora obe strane su morale odustati od svojih nacionalnih ekskluzivizama i maksimalnih zahteva. Sa hrvatske strane za zbližavanje Hrvata i Srba se naročito angažovao Josip Smodlaka koji je nakon Majskog prevrata otišao u Kotor na pregovore sa Srbima. ${ }^{78}$ Pravaška Crvena Hrvatska je pisala da se samo u sporazumu sa Srbima mogu postići hrvatski nacionalni zahtevi u Dalmaciji. ${ }^{79}$ I sam Trumbić koji je bio najskeptičniji po pitanju uspešnog postizanja sporazuma sa Srbima je konačno shvatio da se hrvatska politika u Dalmaciji ne može sprovesti ukoliko se u "domaćim" Srbima imaju neprijatelji. ${ }^{80}$ Među Srbima u Dalmaciji, novoosnovani Novi srpski list je prvi pokazao spremnost da se sa Hrvatima postigne sporazum zarad "čitavog Jugoslavenstva". ${ }^{11} \mathrm{U}$ tom trenutku je i Fabrisovoj dubrovačko-bokokotorskoj grupi Srba-katolika odgovarao sporazum sa dalmatinskim Hrvatima koji bi se politički bazirao na rušenju Austro-Ugarske Monarhije, pogotovo stoga što su političku vlast u Beogradu preuzeli predstavnici antiaustrijske, projugoslovenske i proruske orijentacije. Nova vlada u Beogradu je sigurno imala jakog uticaja na Fabrisovu grupu da postigne sporazum sa Hrvatima. Do prvog sastanka hrvatskih pravaša i Srba dolazi u Dubrovniku 16. jula 1903. Ovom prilikom su goruća pitanja pregovora bila pitanje sudbine Bosne i Hercegovine i pitanje naziva jezika; dva pitanja koja su usko bila povezana. Naime, ukoliko bi se hrvatski jezik proglasio zvaničnim jezikom u Dalmaciji to bi faktički značilo da se ne samo Dalmacija već i Bosna i Hercegovina imaju priključiti Hrvatskoj-Slavoniji. Po istom lingvističko-nacionalnom principu, proglašenje srpskog jezika za zvanični jezik u Dalmaciji je sa sobom podrazumevalo uključivanje ove dve provincije u nacionalnu državu Srba. Shodno tome, u političkom smislu je jedino opcija hrvatsko-srpskog jezika predstavljala pravi modus vivendi, ali je u tom slučaju cena za obe strane bila stvaranje Jugoslavije (tj. južnoslovenskog krpeža) - države, kao rezervne varijante, koju iskreno nije hteo niko.

Skupština Srpske narodne stranke na Primorju koja je održana 14., 15. i 16. avgusta 1903. u Splitu predstavlja prelomni trenutak u hrvatsko-srpskim pregovorima. Na splitskoj skupštini je Fabrisova struja odnela konačnu pobedu unutar stranke. U novom stranačkom programu se odustalo od teze da su Srbi i Hrvati jedan narod, t.j. da su na osnovu jezika Hrvati pleme srpskog naroda, pa je shodno tome i jednima i drugima faktički priznat poseban status narodnosti. Stranka je izrazila nadu da će se podređen položaj Srba u Hrvatskoj-Slavoniji prevazići na taj način što bi se srpsko ime, srpski jezik, pismo, škole i zastava proglasili ravnopravnim sa hrvatskim. Pitanje Bosne i Hercegovine je rešeno tako što je lokalnom stanovništvu ostavljena mogućnost da se izjasni o svojoj sudbini po principu "Balkan-balkanskim narodima" iako se u stranačkom programu ističe "Srpstvo triju vjera". ${ }^{82}$ Može se zaključiti, da je Fabrisov splitski program Srpske narodne stranke na Primorju predstavljao kako značajno odstupanje od ekskluzivizma dotadašnje srpske politike u Dalmaciji tako i najznačajniji korak u približavanju politici "novog kursa". Kao rezultat ovog političkog približavanja dalmatinskih Hrvata i Srba, rad Sabora 1903. je dočekan u pomirljivoj političko-nacionalnoj atmosferi.

\footnotetext{
${ }^{78}$ Ministerium des Inneren, Prasidiale, 22 Dalmatien, Verwaltungsarchiv, Oesterreichisches Staatsarchiv, Wien, 1903, 1567, Zadar, 15. 6. 1903.

${ }^{79}$ Crvena Hrvatska, 24/13. 6. 1903.

80 "Pismo Supila Trumbiću, 24. 6. 1903.", Hajdarhodžić H., Arneri R., Morović H., Nemec M., Korespondencija Frana Supila iz perioda 1891-1914, Arhivski vjesnik, god. 6, sv. 6, Zagreb, 1963, 94.

${ }^{81}$ Novi srpski list, 1/15. 5. 1903.

${ }^{82}$ Dubrovnik, 32/33/34/1903.; Novi Srbobran, 180/1903.; Srpski glas, 35/1903.
} 
Za saborskom govornicim se Ante Trumbić pokazao kao glavni predstavnik "novog kursa". Trumbić je naročito napadao bečku politiku koja je u nameri da centralizuje čitavu zemlju uporno pokušavala da uvede nemački jezik u Dalmaciji. Naime, austrijski ministar-predsednik E. Kerber je u nameri da modernizuje državnu upravu nastojao da u ovoj provinciji proširi primenu nemačkog jezika na štetu italijanskog. U duhu te politike je novi upravnik Dalmacije - Handel - predložio svoju jezičku reformu prema kojoj se upotreba hrvatskog jezika imala proširiti ali se zato sa druge strane u upotrebu uvodio nemački jezik zbog potreba jedinstvene uprave i saobraćaja sa ministarstvima u Beču. Handel je svoju jezičku reformu obrazložio namerom da se narodnom jeziku da ono mesto koje mu pripada ali ne po broju, tj. rasprostranjenosti stanovnika koji tim jezikom govore, već po kulturnom razvitku, tj. nerazvitku, i po stupnju na kojem se taj jezik nalazio. Dalmatinski namesnik je uvođenje nemačkog jezika objašnjavao potrebom efikasnog upravnog poslovanja, jer je bilo po njemu nemoguće, kao što su to poslanici zahtevali, da se korespondencija sa centralnim organima u Beču vodi na osam jezika. Handel je neuspešno pokušavao da ubedi poslanike da se u predlogu njegove jezičke reforme nije radilo o pokušaju podizanja nemačkog jezika na državni nivo. ${ }^{83}$

Karakteristično je da se na Dalmatinskom saboru iz 1903. mnogo govorilo o pokušaju germanizacije Dalmacije preko nemačkog jezika. Handelovom politikom se nemački jezik sve više uvlačio u javne urede, kancelarije, žandarmeriju, sudstvo, poštu, železnice, administraciju i u javnu upravu. Juraj Biankini je čitavu žandarmeriju nazvao "revnim pionirom njemštine" i izjavio pretećim tonom da će se ukoliko se hrvatski jezik ne uvede u žandarmeriju boriti za potpuno ukidanje finansiranja te ustanove iz pokrajinskog budžeta. Svoj stav je obrazložio tvrdnjama da dalmatinska policija predstavlja ustanovu za denacionalizaciju i da upotrebljavajući lokalnom stanovništvu nepoznat jezik policija nije u stanju da efikasno obavlja svoju službu. ${ }^{84}$ Po Biankiniju se isto tako neefikasnom pokazala upotreba nemačkog jezika u sudstvu, pošti i železnicama, gde su se trojezični oglasi, table i dopisi pokazali štetnima jer se hrvatska verzija teksta usled nedovoljnog poznavanja hrvatskog jezika onih koji su ga pisali donosila na nepismen način, tako da je te natpise domaća inteligencija mogla razumeti isključivo čitanjem italijanske verzije teksta, dok ih prosečan Dalmatinac uopšte nije ni mogao razumeti. ${ }^{85}$

Većina hrvatskih poslanika je osudila najnoviji pokušaj vlasti da uvuče nemački jezik u Dalmaciju preko otvaranja vojne škole, a zapravo nemačke gimnazije, u Zadru, finansirane od strane Ministarstva rata. To je napomenuo Pero Čingrija rekavši da se sigurno radi o nemačkoj gimnaziji, budući da se vojna nastava oduvek održavala u kasarnama i za nju nije bila potrebna posebna škola. ${ }^{86}$ Poslanik Prodan je istakao da se denacionalizacija Dalmacije vršila najviše preko pošte jer su kursevi za poštansku službu vršeni na italijanskom jeziku; u poštansku službu su zapošljavani ljudi bez znanja hrvatskog jezika, a onima koji su znali nemački davala se prednost. ${ }^{87}$

\footnotetext{
${ }^{83}$ Brzopisna izvješća Pokrajinskoga sabora dalmatinskoga, 1903, Hander, 679.

${ }^{84}$ Isto, J. Biankini, 732-733.

${ }^{85}$ Isto, 798-799.

${ }^{86}$ Isto, P. Čingrija, 729-730.

${ }^{87}$ Isto, Prodan, 692-694.
} 
Trumbić je kao predstavnik najuticajnije grupe Hrvata u Saboru smatrao da bi se jezičko pitanje u Dalmaciji moglo rešiti veoma brzo i efikasno ukoliko bi vlada "kao stožer riešenja uhvatila hrvatski karakter zemlje i jezik naroda". ${ }^{88}$ Očigledno je da je Trumbić smatrao da s obzirom na pretežno hrvatski karakter Dalmacije, zvanični jezik ove pokrajine treba da bude hrvatski. Pokušaj uvođenja nemačkog jezika je Trumbić okarakterisao kao vekovno nastojanje bečke administracije da germanizuje čitavu državu u cilju kako bi nemački jezik postao zajednička povezujuća nit za sve narodnosti koje su živele u Dvojnoj Monarhiji. Dakle, državno i multinacionalno jedinstvo se trebalo obezbediti i održavati putem upotrebe jedinstvenog zajedničkog državnog jezika. Trumbić je izneo mišljenje da se ovakva lingvistička politika Beča u potpunosti podudarala sa spoljnom politikom Berlina kome je cilj bio da obezbedi istočnu obalu Jadranskog mora za nemačke političko-ekonomske interese. Na kraju, zaključio je da se svi sporovi oko jezika dalmatinskog stanovništva moraju što hitnije rešiti kako bi se Dalmacija mogla što uspešnije odupreti nemačkom prodoru na Jadran. ${ }^{89}$ Josip Smodlaka je izneo uverenje da ne postoji poseban srpski a poseban hrvatski interes u Dalmaciji, t.j. "da između konačnih ciljeva jednog i drugog plemena ne može biti razlike". ${ }^{90}$ Narodnjak Milić je pozdravio srpske poslanike izražavajući im posebnu zahvalnost što su odbili Handelove punktacije o jeziku i pristali da se radi sloge sa Hrvatima jezik u Dalmaciji nazove hrvatski i srpski. Međutim, Milić je smatrao da su ovim gestom Srbi pokazali posebno razumevanje za narodne interese u Dalmaciji; t.j. taj gest nije bio izraz želje da se zaštiti svoj nacionalni jezik a time i ime. Ipak se u ovom slučaju radilo o zaštiti vitalnog nacionalnog interesa Srba u Dalmaciji pa se ne može govoriti o nekakvoj posebnoj politici popustljivosti prema Hrvatima. Milić je prema hrvatsko-italijanskoj saradnji bio potpuno skeptičan napominjući da se granice italijanskog jezika, a time i italijanske nacije, prema italijanskoj iredentistickoj propagandi prostiru cak do Tesalije u Grčkoj! ${ }^{91}$ Koliko je pitanje jezika bilo važno za Italijansku stranku u Dalmaciji može pokazati to što je većina hrvatskih poslanika i političara smatrala da će dalmatinski Italijani eventualno pristati na sjedinjenje Dalmacije sa Banskom Hrvatskom samo pod minimalnim uslovom da im se daju maksimalne garancije za zaštitu svog nacionalnog jezika i kulture. ${ }^{92}$

Pitanje jezika u Dalmaciji se pokazalo jednim od najakutnijih problema ove provincije. Tako su srpski poslanici u duhu načelnog stanovišta Srpske narodne stranke na Primorju odbili da podrže predloženi budžet za osnovno školstvo sa obrazloženjem da u postojećim školskim programima nema dovoljno gradiva iz srpske istorije, da se srpsko ime za jezik i narod uopšte ne spominje, da budžetom nije predviđeno otvaranje posebnih srpskih osnovnih škola u Kninskom kotaru u severnoj Dalmaciji koje bi negovale srpske tradicije i posebno srpski jezik i da nije ustanovljeno mesto za jednog posebnog školskog nadzornika za područje Knina. ${ }^{93}$

\footnotetext{
${ }^{88}$ Isto, Trumbić, 651-652.

${ }^{89}$ Isto, 654-655.

${ }^{90}$ Isto, Smodlaka, 688.

${ }^{91}$ Isto, Milić, 670-672.

${ }^{92}$ Narodni list, 10/1904.

${ }^{93}$ Brzopisna izvješća Pokrajinskoga sabora dalmatinskoga, 1903, Vukotić, 619.
} 
Nakon zasedanja Sabora, glavni cilj nosilaca politike "novog kursa" je bio da se akutno pitanje jezika javno raspravi među narodom Dalmacije naročito sada kada je Handelovom jezičkom reformom pretila germanizacija i denacionalizacija provincije u ime "austrijskog patriotizma". Na sastanku održanom u Trumbićevom stanu 29. novembra 1903. najistaknutije vođe "novog kursa" su donele odluku da se u decembru iste godine održe narodne skupštine širom Dalmacije na kojima bi se raspravljalo o sledeće četiri tačke među kojima je prva bila ujedno i najvažnija: 1) pitanje jezika, 2) vinska klauzula, 3) sjedinjenje Dalmacije sa Hrvatskom-Slavonijom i 4) hrvatsko-srpsko-italijanski odnosi. ${ }^{94}$ Sem pokretanja javnih rasprava o ovim gorućim pitanjima u Dalmaciji, politika "novog kursa" je dobila snažan polet početkom 1904. kada se pojavio preuređeni riječki Novi list sa urednikom F. Supilom kao glasilo pokreta. U novogodišnjem uvodniku lista se isticalo da je sređivanje nacionalnih odnosa sa Srbima na ravnopravnim osnovama i sprovođenje politike duhovnog jedinstva svih Južnih Slovena uključujući i Bugare jedan od ključnih prioriteta pokreta. ${ }^{95} \mathrm{O}$ Srbima u Hrvatskoj se pisalo u duhu hrvatsko-srpske saradnje što je i bio jedan od ciljeva pokreta. Posebno se isticalo na opasnost ponemčavanja provincije prodorom nemačkog jezika u javne poslove i službe.

Rusko-japanski rat koji je izbio 1904. dao je dobar povod i Srbima i Hrvatima na celokupnom južnoslovenskom etnografskom prostoru da izraze svoje simpatije prema Slovenstvu i u svakom slučaju je olakšao međusobno približavanje. Prekid neprijateljstava i međusobnih optužbi u štampi na obe strane označilo je početak novih hrvatskosrpskih odnosa u Dalmaciji. Tako je sredinom 1904. došlo do promene urednika u Srpskom glasu koji je pod novim uredništvom Dimitrija Marčetića znatno ublažio stav prema Hrvatima izbegavajući politiku krajnjeg radikalizma. Na jačanje hrvatsko-srpske saradnje u Dalmaciji sredinom 1904. je odlučujuće uticala Handelova politika germanizacije provincije nezakonitim uvođenjem i zaštitom nemačkog jezika kao i zapošljavanjem nemačkih činovnika u administraciji. Zbog bečke politike prema Dalmaciji ova provincija je od strane domaćeg stanovništva nazivana čak i "nemačkom kolonijom". ${ }^{96}$ Politika germanizacije u čitavoj državi je vodila tome da nacionalni jezici dobiju lokalni karakter a da jezik državnog centra u Beču postepeno postaje i jezik vojske, policije, diplomatije i administracije ako ne u čitavoj Dvojnoj Monarhiji ono bar u Cislajtaniji. Otvaranje muške učiteljske škole u Arbanasima kraj Zadra je takođe protumačeno kao smišljena politika denacionalizacije slovenskog življa u Dalmaciji jer je škola otvorena zbog austrijskih potreba da širi austro-nemački uticaj u Albaniji na albanskom jeziku. ${ }^{97}$ Takođe, čitav školski sistem i nastavni programi su bili tako koncipirani da razvijaju "austrijski patriotizam" a ne etnički nacionalizam. Tako se slovenska istorija nedovoljno predavala, Dalmacija se nije predstavljala kao južnoslovenska zemlja a maternji jezik se čak nije ni nazivao nacionalnim jezikom. ${ }^{98}$

\footnotetext{
${ }^{94}$ Ministerium des Inneren, Prasidiale, 22 Dalmatien, Verwaltungsarchiv, Oesterreichisches Staatsarchiv, Wien, 1903, 22/geh., Zadar, 18. 12. 1903; Tajni spisi Namjesništva, 833/res., Split, 20. 12. 1903, Historijski Arhiv u Zadru.

${ }^{95}$ Novi list, 1. 1. 1904.

${ }^{96}$ Narodni list, "Nemačka kolonija", 55/1904.

${ }^{97}$ Brzopisna izvješća Pokrajinskoga sabora dalmatinskoga, 1903., Marović, 614

${ }^{98}$ Isto, 1903., Perić, 606.
} 
Potpuna pobeda politike "novog kursa" na polju južnoslovenske saradnje u Dalmaciji je došla do izražaja prilikom izbora za Carevinsko veće i naknadnih izbora za Dalmatinski sabor. Naime, u oba ova slučaja su Srbi ne samo pristali da stupe u koaliciju sa pravašima već i da glasaju za pravaške kandidate. Pobeda nove politike u Dalmaciji se očitovala i u tome što su 1905. hrvatsko-srpski dalmatinski poslanici u Carevinskom veću u Beču zajedno podneli memorandum novom ministru predsedniku baronu fon Frankenturnu tražeći između ostalog i da se pitanje administrativnog jezika u pokrajini reši u duhu odluka Dalmatinskog sabora iz 1884 . $^{99} \mathrm{U}$ to vreme su hrvatsko-srpski predstavnici politike "novog kursa" bili znatno ohrabreni u svojim zahtevima istupanjem ujedinjene mađarske opozicije, koja je pobedila na izborima za mađarski parlament, protiv austrijskog centralizma zahtevajući da se u mađarskom delu zajedničke carsko-kraljevske vojske proglasi mađarski jezik za komandni što je praktično značilo traženje posebne mađarske vojske. ${ }^{100}$

Izborna pobeda mađarske opozicije je ubrzala političku fuziju hrvatskih pravaša i narodnjaka u Dalmaciji u jedinstvenu Hrvatsku stranku koja je donela svoj politički program na zasedanju u Splitu 26./27. aprila 1905. U četvrtoj tački programa je naglašeno "da su Hrvati i Srbi jedan narod po krvi i po jeziku, nerazdruživo spojeni zemljištem, na kojem obitavaju" i da će Hrvatska stranka raditi na tome "da se uklone i onemoguće razmirice, a da se uvriježi ljubav među njima, na osnovi zdravog samokupnog rada za opći narodni boljitak". Prema ideološkoj koncepciji kao i programu novonastale stranke čiji je predsednik postao Pero Čingrija, upravo je "zajednički jezik" činio Hrvate i Srbe jednim narodom, dok se prema trećoj tački programa vera nije smela mešati sa narodnošću jer "razlika vjeroispovesti ne može i ne smije biti zaprekom složnom narodnom radu". Iz ideološkog stava da su Hrvati i Srbi jedan narod istog jezika proizlazio je i logičan stav da bi se taj jezik trebao nazvati zajedničkim hrvatsko-srpskim imenom što je moglo samo još više da doprinese međunacionalnoj saradnji ova dva naroda. ${ }^{101}$ Isti stav po pitanju naziva nacije i jezika je zauzela dalmatinska omladina koja je uz veliki uticaj J. Smodlake u avgustu 1905. osnovala posebnu stranku pod imenom Hrvatsko demokratsko političko društvo u Splitu.

Međutim, upravo zbog pitanja naziva jezika Hrvata i Srba došlo je do nepoverenja Srpske narodne stranke na Primorju u iskrenost A. Trumbića prema dalmatinskim Srbima. Naime, Trumbić nije na insistiranje Dubrovnika da se konkretno izjasni o nazivu jezika u Dalmaciji to učinio što je protumačeno od strane uredništva lista kao nastavljanje stare pravaške politike da se Dalmacija tretira isključivo kao hrvatska teritorija na kojoj pored Italijana žive samo Hrvati ali ne i Srbi. Proklamovano načelo o jednom narodu iste krvi i jezika je protumačeno od strane srpskih narodnjaka oko Dubrovnika kao plašt ispod koga se krije hrvatska nacija i hrvatski jezik. Dubrovački Srbi su naročito insistirali da se u Dubrovniku srpski jezik pored hrvatskog proglasi zvaničnim kao i da se pored hrvatske zastave na opštinskoj zgradi vijori i srpska zastava što bi po njima bio pravi dokaz priznavanja srpske nacije kao ravnopravne sa hrvatskom. Dok je hrvatska strana ove zahteve u načelu prihvatila, pitanje oko proporcijalnog ili paritetnog principa popunjavanja predstavničkih i upravnih tela u opštini je ostalo nerešeno. ${ }^{102} \mathrm{U}$

\footnotetext{
${ }^{99}$ Novi list, 41/1905.

${ }^{100}$ Ovaj zahtev je bio potpuno legitiman jer se zasnivao na 12.-om članu Austro-ugarske nagodbe iz 1867.

${ }^{101}$ Program Hrvatske stranke u Dalmaciji, Zadar, 1905.; Narodni list, 45/7. 6. 1905 i 40/20. 5. 1905., Trumbićev komentar programa.

${ }^{102}$ Dubrovnik, 34/1905.
} 
suštini, dobar deo dubrovačkih Srba je u novonastaloj Hrvatskoj stranci video političku organizaciju koja sprovodi (veliko)hrvatski program a ne jugoslovenski. ${ }^{103}$

Za razliku od hrvatsko-srpskih pregovora, u leto 1904. sasvim suprotno nego što je to bilo 1903., hrvatsko-italijanski sporazum je izgledao daleko dalji i teži nego sporazum Hrvata i Srba. Razlog za ovu činjenicu je bio trojakog karaktera: 1) nepopustljivost hrvatskih političara da priznaju italijanski jezik pored hrvatskog za zvanični jezik u Dalmaciji što bi za Italijane predstavljalo fundamentalni dokaz nacionalne ravnopravnosti, 2) političko razilaženje oko Rusko-japanskog rata jer su Hrvati i Srbi podržavali Rusiju a Italijani Japan, i 3) nastojanje Italijana da nacionalno pitanje i pitanje jezika nametnu kao politički problem a ne kao pitanje kulturne prirode. ${ }^{104}$

\section{Riječka i Zadarska rezolucija i stvaranje hrvatsko-srpske koalicije}

U Rijeci (Fiume), u dvorani Hrvatske čitaonice, je 2. i 3. oktobra, 1905. održan istorijski sastanak hrvatskih opozicionih saborskih poslanika koji je usledio nakon uspešnog postizanja dogovora između hrvatske i mađarske parlamentarne opozicije o zajedničkom političkom radu protiv austrougarskih vladajućih krugova. Saradnja sa mađarskim, ali isto tako i sa srpskim, opozicionim snagama je za politiku "novog kursa" bio jedini put ka dolasku na vlast radi izmene političko-ekonomskog stanja u Dalmaciji i Hrvatskoj-Slavoniji. Riječkom sastanku su prisustvovali predstavnici svih političkih grupa sem mađaronske Narodne stranke i Čiste stranke prava.

Riječka konferencija je održana pod geslom: "Austrija je izvor svega našega zla u prošlosti i sadašnjosti; sa Mađarima, pored svega, želimo sporazum kao narod sa narodom u obostranom interesu". ${ }^{105} \mathrm{U}$ toku riječkih razgovora, pored političko-ekonomskih pitanja, vidno mesto je zauzeo problem međunacionalnih odnosa Hrvata i Mađara koji se reflektovao ponajviše kroz pitanje jezika. Predstavnici "novog kursa", a ponajviše Vrbančić, radi uspostavljanja ravnopravnih hrvatsko-mađarskih odnosa, zahtevali su na prvom mestu da se sa mađarske strane poštuje uredba o jeziku iz Hrvatsko-ugarske nagodbe (1867.) prema kojoj je na čitavoj teritoriji Hrvatske-Slavonije službeni jezik isključivo bio hrvatski, kako u autonomnim tako i u zajedničkim poslovima. ${ }^{106}$ Shodno tome, trebala se voditi i personalno-kadrovska politika pri promovisanju ili premeštanju činovnika u službama zajedničkih poslova, tj. da te poslove vode hrvatski službenici na hrvatskom jeziku. ${ }^{107}$ Ovde je bitno napomenuti da se zahtevalo da se i u zajedničkim hrvatsko-mađarskim poslovima upotrebljava hrvatski jezik sa hrvatske strane što je praktično značilo da je Budimpešta dužna da na hrvatskom jeziku komunicira za Zagre-

\footnotetext{
${ }^{103}$ Isto, 41/8. 10. 1905. O pitanjima nacionalne politike u Dalmaciji za vreme tzv. narodnog preporoda videti u: Antoni Cetnarowics, Narodni preporod u Dalmaciji, Zagreb, 2006.

${ }^{104}$ Govori Zilotija i Salvija u Dalmatinskom saboru kao i beleške sa hrvatsko-italijanskih pregovora koje se nalaze u zaostavštini Ante Trumbića, Arhiv Ante Trumbića, Znanstvena knjižnica u Splitu; Narodni list.

${ }^{105}$ Trumbić A., Suton Austro-Ugarske i Riječke rezolucije, Zagreb, 1936, 85.

${ }^{106}$ Hrvatski tekst "Hrvatsko-ugarske nagodbe" vidi u: Bojničić I. (urednik), Zakoni o ugarsko-hrvatskoj nagodi, Zagreb, 1907.

${ }^{107}$ Milić V., Postanak Riječke rezolucije i njezine posljedice, Zadar, 1907, 10; Trumbić A., Suton Austro-Ugarske i Riječke rezolucije, Zagreb, 1936, 86.
} 
bom. Sem potvrde nacionalne individualnosti, ovim zahtevom se praktično želelo obezbediti da Hrvati dobiju širi uvid u rad zajedničkih službi a naročito kontrolu nad zajedničkim finansijskim poslovima. ${ }^{108}$ Vuković, kao i Biankini i Ivčević, se zalagao za odbranu prava hrvatske nacije putem promovisanja hrvatskog jezika kao zvaničnog u administraciji ali i vojsci na hrvatskoj teritoriji napominjući da Hrvati neće ništa dobiti ukoliko se nemački jezik u vojsci zameni mađarskim. Da bi osigurali poštovanje hrvatskih nacionalnih prava, pojedini učesnici konferencije, kao Majstorović, su podsećali da se ne sme zaboraviti na Srbe iz Trojednice pa stoga se u rezoluciji mora naći mesta za isticanje jedinstva Hrvata i Srba, pa i Slovenaca. ${ }^{10}$

Tekst Riječke rezolucije je prihvaćen drugog dana konferencije od strane 31 poslanika dok 9 poslanika nije želelo da potpiše rezoluciju. Riječka rezolucija je bila potpuno u duhu politike "novog kursa". Njome je istaknut zajednički političko-nacionalni rad hrvatskog i mađarskog naroda, odnosno hrvatske i mađarske opozicije radi državno-pravnog osamostaljenja Ugarske i sjedinjavanja Dalmacije sa Hrvatskom i Slavonijom. Na kraju rezolucije, hrvatski narodni zastupnici su izrazili uverenost da će se na kraju postići trajni hrvatsko-mađarski sporazum kome bi garant bila dva uslova: 1) poštovanje hrvatskih narodnih prava sadržanih u postojećoj Hrvatsko-ugarskoj nagodbi, i 2) promena u odnosima iz područja poslova koji su zajednički sa Budimpeštom i Bečom na takav način da "hrvatskom narodu bude obezbeđen samostalni politički, kulturni, financijski i opće gospodarstveni opstanak i napredak". ${ }^{110}$ Ovde je najbitnije istaći da su potpisnici rezolucije smatrali da je uvođenje hrvatskog jezika kao zvaničnog u Trojednici, kao i opštenje sa zajedničkim upravnim organima u Budimpešti na hrvatskom jeziku bio conditio sine qua non ne samo dokazu o priznavanju ravnopravnog statusa hrvatske sa mađarskom nacijom već i osnovni uslov za hrvatsko-mađarsku saradnju.

Ipak, jedan od najbitnijih nedostataka teksta Riječke rezolucije je bilo nespominjanje Srba i Italijana. Ovi poslednji nisu uneti u rezoluciju jer hrvatske opozicione stranke nisu još uvek uspele da se sporazumeju sa Italijanskom strankom u Dalmaciji usled nemogućnosti da ispune italijanski zahtev po pitanju italijanskog jezika. Na drugoj strani, sa dalmatinskim Srbima je bilo velikih izgleda da će se konačno postići separatni dogovor koji bi bio overen potpisivanjem posebne rezolucije što se nešto kasnije i dogodilo u Zadru.

Nakon donošenja Riječke rezolucije hrvatske opozicione stranke su nastavile pregovore sa dalmatinskim Italijanima i Srbima kako bi obezbedile i na toj strani podršku odlukama u Rijeci. Italijanska stranka je 16. oktobra 1905. izdala saopštenje u kojem je ponovila zahteve italijanskog nacionalnog autonomnog pokreta ističući da je njihov osnovni zadatak zaštita italijanskih nacionalnih prava prevashodno preko zaštite italijanskog nacionalnog jezika. Međutim, zaštita tih prava se tražila ne u srazmeri prema broju italijanskih stanovnika u Dalmaciji, nego prema kulturi i ekonomskom stanju i pomoći koju Italijanstvo pruža u dalmatinskoj borbi protiv Nemstva. Prema ovakvoj koncepciji obrazloženja, sasvim je razumljivo zašto je Italijanska stranka kao osnovni zahtev oduvek isticala proglašenje italijanskog jezika za jedan od zvaničnih jezika u Dalmaciji, te da se u tom smislu uči u svim školama pokrajine od osnovnih do srednjih, opšteobrazovnih i stručnih kao obavezan predmet, da se italijanskim školama "II Nazionale" prizna javnost i osigura

\footnotetext{
${ }^{108}$ Koncept Zapisnika sa sjednice na Rijeci, Arhiv Ante Trumbića, Znanstvena knjižnica u Splitu, M 417, 21.

${ }^{109}$ Arhiv Pere Čingrije, Historijski arhiv u Dubrovniku, X 7 F, a3, ab.

${ }^{110}$ Horvat J., Politička povijest Hrvatske, Zagreb, 1990, 274.
} 
subvencioniranje iz pokrajinskog fonda za školstvo i da svi natpisi, grbovi i slična javna obaveštenja budu napisana na dva jezika: hrvatskom i italijanskom. Prema saopštenju, do italijansko-hrvatskog sporazuma još uvek nije moglo doći usled "neuvažavanja italijanske manjine" od hrvatske strane. Saopštenje se završava konstatacijom da s obzirom da još uvek ne postoje garancije da će hrvatska strana usvojiti italijanske zahteve, Italijanska stranka zadržava pravo "najapsolutnije rezerve i slobode akcije". ${ }^{111}$ Hrvatska strana je ovakvo italijansko saopštenje odbila uz obrazloženje da je italijanski cilj da se Dalmacija proglasi dvonacionalnom, hrvatsko-italijanskom, teritorijom. Očigledno je da je u ovom trenutku politika "novog kursa" prema Italijanskoj stranci doživela potpun neuspeh.

Riječka rezolucija nije u početku ni od Srpske narodne stranke na Primorju dočekana sa puno hvale. Stranački organ Dubrovnik je u tekstu rezolucije video licemerje hrvatskih opozicionih stranaka jer je u originalnoj verziji rezolucije stajalo da će ona "udariti pravac političkome radu u pitanjima koja su neprijeporna i cijelome hrvatskom narodu zajednička". Dubrovnik je podsećao da Hrvati i "sami znadu, da toga zajedničkoga neprijepornoga pitanja nema, ako izuzmeš samo pitanje jezika". ${ }^{12}$ Stranačko glasilo Srpske narodne stranke na Primorju je ovaj svoj stav objašnjavalo na sledeći način: s obzirom da hrvatska politika pod terminom "neprijepornim pitanjem" podrazumeva u stvari težnju za ujedinjenjem hrvatskog naroda i postizanje hrvatske državnosti na tzv. celokupnom istorijskogeografskom prostoru hrvatskog entiteta pod kojim se podrazumevala i Dalmacija i Bosna i Hercegovina, Srpska narodna stranka na Primorju takve težnje nije mogla podržati. Stranka tvrdi da ne postoji nijedno pitanje sem pitanja jezika koje bi i Hrvatima i Srbima bilo nesporno i na kojem bi mogli izgraditi pravac zajedničkog političko-nacionalnog rada.

Ipak, zauzimanjem i političkim delovanjem srpskih stranačkih prvaka iz Hrvatske-Slavonije, uskoro je ipak došlo do hrvatsko-srpskog sporazuma, kome je prethodilo prihvatanje teksta Riječke rezolucije od strane srpskih političkih stranaka na sastanku u Zadru što je sve skupa dovelo do stvaranja Hrvatsko-srpske koalicije. Naročito je najjača srpska stranka u Banovini - Srpska narodna samostalna stranka - insistirala na stvaranju prisnijih političkih veza sa hrvatskim opozicionim strankama pa čak i sa hrvatskim pravašima. Tako je maja 1904. na sednici Centralnog odbora stranke u Zagrebu u načelu primljena izborna koalicija sa Hrvatskom strankom prava za Sabor Kraljevine Hrvatske i Slavonije. ${ }^{113}$ Pod kojim uslovima bi srpska strana pristupila u koalicionu saradnju sa hrvatskom stranom izrečeno je avgusta meseca iste godine na sastanku srpskih samostalaca u Vojki. Tom prilikom je na prvom mestu naglašeno da je do saradnje moguće doći pod uslovom ukoliko se srpskom imenu dodeli ravnopravan status sa hrvatskim imenom. To je sa svoje strane podrazumevalo da se i srpskoj pravoslavnoj crkvi dodeli ravnopravan status sa rimokatoličkom crkvom, kao i ćirilice sa latinicom, srpskog jezika sa hrvatskim kao i da se obezbedi upotreba srpske zastave. ${ }^{114}$ Dakle, kao dokazi postojanja srpskog naroda u Banovini (Hrvatskoj i Slavoniji pod upravom bana) se navode nacionalno

\footnotetext{
${ }^{111}$ Ovo "Saopštenje" je štampano u Narodnom listu a nalazi se takođe u Trumbićevoj knjizi Suton AustroUgarske i Riječke rezolucije, Zagreb, 1936, 59-94.

${ }^{112}$ Dubrovnik, 41/8. 10. 1905., Prilog.

${ }^{113}$ Krestić Đ., Građa o Srbima u Hrvatskoj i Slavoniji (1848-1914), knjiga II, Beograd, 1995, "Zapisnik sednice Centralnog odbora Srpske narodne samostalne stranke, 27. maj, 1904.", 385-386.

${ }^{114}$ Arhiv Hrvatske u Zagrebu, Predsednički spisi zemaljske vlade, "Podžupan vukovarski Predsedništvu zemaljske vlade, Vukovar, 28. avgusta 1904.", kutija 655, dokument 3621 Pr., 1904.
} 
pismo, jezik, vera i zastava. Iste koalicione uslove je isticala i Srpska narodna radikalna stranka uz poziv na stvaranje hrvatsko-srpskog izbornog sporazuma. ${ }^{115} \mathrm{U}$ međuvremenu, srpski samostalci i radikali su taj sporazum postigli. ${ }^{116}$

Koliko je pitanje jezika i vere bilo važno za srpske stanovnike Banovine može nam pokazati molba upravnog odbora srpske pravoslavne crkvene opštine u Zemunu u kojoj se traži od vlade Hrvatske da se srpski jezik više ne naziva hrvatskim imenom, da se srpski književnici ne ubrajaju među hrvatske pisce i da se srpska pravoslavna vera ne naziva "grčko-nesjedinjenom". ${ }^{117}$ Hrvatski otpor upotrebi srpskog ćiriličnog pisma se zasnivao na strahu da se pojedini delovi Banovine sa većom koncentracijom de facto srpskog stanovništva ne otrgnu procesu kroatizacije, tj. ne posrbe. Tako su se, na primer, septembra 1905. hrvatski građani Gospića iz Like žalili vlastima zbog navodno smišljenog posrbljavanja Like dozvolom upotrebe srpskih zastava i korišćenja ćirilice. ${ }^{118}$

Srpski političari iz Banovine skloni saradnji sa hrvatskim opozicionim strankama su navodili sledeće pogodne političke uslove koji su se stvorili u Hrvatskoj-Slavoniji i Dalmaciji vezanim za postizanje hrvatsko-srpskog dogovora: 1) sve hrvatske stranke uključujući i pravaše su napustile program hrvatskog istorijskog državnog prava, koji je bio osnova dotadašnjoj njihovoj politici, a bio je uperen prevashodno protiv srpskog naroda kome nisu priznavani nacionalna posebnost, jezik, pismo i zastava, 2) hrvatska politika je prema Riječkoj rezoluciji prekinula sve veze sa Bečom, koji je Hrvatstvo favorizovao protiv Srpstva, i 3) nakon Riječke rezolucije se uočava novi politički pravac delovanja hrvatskih stranaka koji nije težio sjedinjenju Bosne i Hercegovine sa Banovinom već samo Dalmacije. ${ }^{119}$

Postoji više razloga zašto je Srpska narodna samostalna stranka u Dalmaciji na kraju pristala da se priključi politici Riječke rezolucije. Prvo, hrvatske stranke potpisnice rezolucije su pokazale veliku odlučnost u sprovođenju politike "novog kursa" pa su srpski samostalci shvatili da bez hrvatske opozicije ne mogu uticati na politički život Dalmacije. Drugo, dalmatinski Srbi su bili isto kao i Hrvati ozlojeđeni austrijskom upravom i politikom u Dalmaciji. Treće, hrvatska politika "novog kursa" se vremenom mogla usmeriti ka jugoslovenskoj ideji i ujedinjenju svih Južnih Slovena a time i Srba. Četvrto, srpski političari u Dalmaciji su se nalazili pod jakim uticajem i pritiskom nove vlade u Beogradu da pronađe sporazum sa Hrvatima radi stvaranja jednog antinemačkog italijansko-hrvatsko-srpskomađarskog bloka. Peto, sloga sa Hrvatima je bila poželjna unutar programa ujedinjenja svih srpskih zemalja. I konačno, na promenu politike Srpske narodne samostalne stranke u Dalmaciji prema Riječkoj rezoluciji je presudno uticao stav Srpske narodne samostalne stranke u Hrvatskoj-Slavoniji.

\footnotetext{
${ }^{115}$ Vojvođanski muzej, Radikalna stranka, "Đorđe Krasojević upravama hrvatskih opozicionih stranaka nudi izborni sporazum za zemaljski sabor, Sremski Karlovci, 3./16. januar 1905.”, broj 4037/27.

${ }^{116}$ Isto, broj 4096 i 4097.

${ }^{117}$ Arhiv Srpske Akademije nauka i umetnosti, Sremski Karlovci, "Zapisnik sednice Školskog saveta, Sremski Karlovci, 3./16. avgusta 1905.", Školski savet, broj 464/1905.

${ }^{118}$ Arhiv Hrvatske u Zagrebu, Predsednički spisi zemaljske vlade, "Hrvatsko građanstvo Gospića velikom županu Tomi Kraljeviću, Gospić, 7. septembar 1905.”, kutija 661, dokument 3176 Pr. 1905.

${ }^{119}$ Vojvođanski muzej, Radikalna stranka, "Bogdan Medaković i Svetozar Pribićević Đorđu Krasojeviću, Zagreb, 6. oktobar 1905”, broj 4099; Isto, “Svetozar Pribićević Đorđu Krasojeviću, Zagreb, 20. oktobar 1905.”, broj 4098.
} 
Do sastanka srpskih stranaka u Zadru, na kojem je doneta tzv. Zadarska rezolucija, je došlo najviše nastojanjem srpskih samostalaca iz Banovine. Tekst rezolucije je 17. oktobra 1905. sastavio odbor koji su sačinjavali Pribićević, Krajnović, Miladinović, Babić, Pugliesi i Desnica a potpisan je od strane predstavnika Srpske narodne samostalne stranke, Srpske narodne radikalne stranke i Srpske narodne stranke na Primorju. Zadarskom rezolucijom se u osnovi podržava slična rezolucija doneta u Rijeci kao i pokret mađarske opozicije jer je bio uperen protiv politike Beča koja sputava razvitak "naše otadžbine hrvatskog i srpskog naroda". Srpska strana je hrvatskoj ponudila sporazum prema kome bi Hrvati i Srbi zajednički radili na tome da se Banovini "zajamči što samostalniji politički, kulturni, privredni i financijski opstanak i razvitak". Međutim, što se ticalo pitanja sjedinjenja Banovine sa Dalmacijom srpske stranke potpisnice Zadarske rezolucije su iznele stav da će takav akt podržati samo u slučaju ako se sa hrvatske strane pristane na paritetnu ravnopravnost srpskog naroda sa hrvatskim. ${ }^{120}$ Pod tom ravnopravnošću se podrazumevalo priznavanje postojanja srpskog jezika i njegove jednake upotrebe sa hrvatskim, kao i ćirilice sa latinicom, priznavanje postojanja srpske pravoslavne vere kao i upotrebe srpske zastave pored hrvatske zastave (u osnovi su, inače, obe bile iz Srbije).

Sledeći korak nakon potpisivanja Riječke i Zadarske rezolucije bio je potpisivanje zajedničkog hrvatsko-srpskog sporazuma kojim bi se stvorila hrvatsko-srpska politička koalicija radi zajedničkog nastupanja na predstojećim izborima. Sa srpske strane je za pregovore sa hrvatskim predstavnicima izabran Odbor od tri lica sa njihovim zamenicima (Medaković, Krasojević, Pugliesi/Pribićević, Miladinović, Desnica). Pregovori su održani skoro mesec dana nakon potpisivanja Zadarske rezolucije, 14. novembra 1905. u zgradi Zemaljskog odbora u Zadru. Sporazum je konačno postignut istog dana i to između poslaničkih klubova Hrvatske stranke i Srpske narodne stranke na Dalmatinskom saboru. Sa hrvatske strane su ovaj sporazum potpisali čak i oni poslanici koji nisu potpisali Riječku rezoluciju. Sporazumom je na prvom mestu naglašeno da su Hrvati i Srbi jedan narod, da su jedni prema drugima ravnopravni, i da će zajedničkim snagama raditi na narodnom sjedinjenju. Kao najopipljiviji dokaz međunacionalne ravnopravnosti zaključeno je da se naziv narodnog jezika "koji je Hrvatima i Srbima jedan te isti" nazove "hrvatskim ili srpskim" pozivajući se na zaključak Dalmatinskog sabora od 21. jula 1883. Shodno tome "sve zakonske osnove i svi zaključci, koji budu glasovani u Dalmatinskom saboru, a u kojim bude spomenut naš narodni jezik, isti će se i u naprijed nazivati hrvatskim ili srpskim. Obe stranke nastojaće i poradiće, da zakonske osnove i svi zaključci, koji budu glasovani u Carevinskom vijeću, a u kojim bude spomenut naš narodni jezik, budu nazivali naš jezik hrvatskim ili srpskim, kao također da isti naziv budu upotrebljavali sve državne vlasti i uredi. U svim zajedničkim izvanparlamentarnim manifestacijama stranke hrvatske i srpske, i njihovih klubova, narodni jezik nazivaće se uvijek hrvatskim ili srpskim. Naravno je pak, da u posebnim manifestacijama jedne i druge stranke i njihovih klubova, slobodno je svakoj strani da nazivlje narodni naš jezik samo hrvatski ili samo srpski, kako je jednomu ili drugomu dijelu naroda prirodnije". Obe stranke su se obavezale da se hrvatskom i srpskom imenu, jeziku i pismu dodeli dostojno mesto u javnim školama u Dalmaciji, da se u školskim tekstovima izučava sa obe strane i hrvatska i srpska istorija, "i da se oba pisma, latinsko i ćirilsko budu toliko i tako učili, da učenici postanu

${ }^{120}$ Dubrovnik, 43/1905. Tekst Zadarske rezolucije su donele sve tadašnje hrvatske i srpske novine. 
vješti jednomu i drugomu pismu u čitanju i pisanju". Konačno kao vidan znak međunacionalne ravnopravnosti, zaključeno je da se hrvatska i srpska zastava vijore zajedno tamo gde u opštinskim većima ima najmanje jedna trećina Srba ili u opštini znatan broj srpskog stanovništva, te da se rešenja svih podnesaka kod autonomnih vlasti izdaju na pismu kojim je taj isti podnesak napisan. ${ }^{12}$

Hrvatsko-srpski sporazum je u Dalmatinskom saboru prihvaćen od svih poslanika s tim što su pojedini poslanici imali drukčiji stav prema shvatanju pojma "jedan narod" u odnosu kako je taj pojam definisan u samom sporazumu. Tako je poslanik Prodan izneo mišljenje da ukoliko su Hrvati i Srbi jedan narod on ne vidi razloga zašto bi Srbi imali nekakva posebna prava u odnosu na Hrvate kao što su pravo na poseban naziv jezika, isticanje zastave i učenje posebne srpske istorije. Ovako je izgledalo kao da su Srbi poseban narod u odnosu na Hrvate i da zastupaju drugu političku misao. ${ }^{122}$ Očigledno je da je Prodan zastupao gledište o "jedinstvenosti naroda" za razliku od srpskih ideologa koji su insistirali na terminu "dvoplemenog naroda" pa su shodno takvom shvatanju i insistirali na posebnom srpskom jeziku, pismu i zastavi koji su trebali da predstavljaju najočigledniji dokaz posebne plemenske, tj. narodnosne, pripadnosti. Srpske stranke su sa svoje strane pozdravljale odrednicu sporazuma o jednom hrvatsko-srpskom narodu jer se tom odrednicom isticalo da Srbi u Dalmaciji nisu nacionalna manjina već ravnopravna paritetna strana.

Slovenski svet je sa zadovoljstvom prihvatio ovaj u suštini antibečki sporazum hrvatskih i srpskih stranaka u Dalmaciji. To je jedan od razloga što od tada jača jugoslovenska ideja pa tako istovremeno u jugoslovenskom duhu pišu i hrvatska Sloboda i srpski Dubrovnik. Nakon sporazuma, većina hrvatskih glasila je pisala da u pregovore sa mađarskom opozicijom treba ići sa jugoslavenstvom a ne sa hrvatstvom, jer je ova poslednja koncepcija daleko slabija od prethodne. Tada se po prvi put javila ozbiljna misao o stvaranju Jugoslavije kojoj bi okosnica bile Srbija (kao Pijemont) i Hrvatska (kao Toskana). U Hrvatskoj-Slavoniji je politika "novog kursa", ojačana nakon hrvatsko-srpskog sporazuma u Dalmaciji, dovela konačno do stvaranja Hrvatsko-srpske koalicije 1906. koja je dobila većinu poslaničkih mandata u Hrvatskom saboru na izborima iste te godine. ${ }^{123}$ Time je bila osigurana pobeda jugoslovenske orijentacije u hrvatsko-srpskoj politici u Trojednici. O pravim osnovama hrvatsko-srpskog sporazuma je možda u to vreme najbolje pisao zagrebački Obzor: "...Hrvati i Srbi imadu isti jezik, iste običaje, iste oznake. Vjeru ne možemo uzeti mjerilom. Preostaje samo dvojaka organizacija, dvojako ime i dvojaka svijest". ${ }^{124}$

${ }^{121}$ Arhiv Srpske Akademije nauka i umetnosti, Fond dr. F. Nikića, "Sporazum sa Hrvatima, Zapisnik sastavljen u uredu Zemaljskog odbora u Zadru, dana 14./1. novembra 1905.", broj 14.528; Dubrovnik, 47/1905; Arhiv Ante Trumbića, Znanstvena knjižnica u Splitu, M 415. Videti takođe i: "Proglas hrvatske i srpske opozicije”, Novi Srbobran, 15. decembar 1905.

${ }^{122}$ Brzopisna izvješća Pokrajinskoga sabora dalmatinskoga, 1905., Prodan, 1457-1458, 1461, 1468-1469.

${ }^{123}$ O prvoj godini vladavine Hrvatsko-srpske koalicije videti u: Gross M., Vladavina Hrvatsko-srpske koalicije 1906-1907, Beograd, 1960.

${ }^{124}$ Obzor, "Narodnosno pitanje u Hrvatskoj", 12. februar, 1907. Srbi i Hrvati u to vreme kao i danas imaju isti standardizovani ili književni jezik ali iz razloga jer su Hrvati "pozajmili" srpski jezik, tj. štokavsko narečje a sa njim i kulturno-nacionalno blago nastalo na ovom narečju. "Pozajmljivanje" jezika je samo jedan u nizu primera hrvatske povesne kleptomanije - procesa u kome su najdeblji kraj izvukli Srbi što se takođe odnosi i na suživot sa Hrvatima u zajedničkoj državi nakon 1918. Ta zajednička država je pre svega bila krpež sastavljen od mnogih etničkih, kulturnih verskih i regionalnih raznolikosti tako da već u samom startu nije imala većih izgleda na neki duži opstanak (Gowland D., Dunphy R., Lythe Ch., The European Mosaic, Harlow, 2006, 489). 


\section{Zaključak}

Do radikalnog zaokreta u pogledu naziva naroda i službenog jezika u Dalmaciji kao i u Hrvatskoj i Slavoniji došlo je u onom trenutku kada je počela da se širi politika "novog kursa". Većina hrvatskih stranaka je odbacila načela stare političke ideologije iz XIX veka zasnovane na načelima navodnog državnog i istorijskog prava Hrvata i Hrvatske, iz kojih je proizlazila ideja o "hrvatskom političkom narodu" koja je predstavljala realnu osnovu za asimilaciju i kroatizaciju Srba u Trojednici. U isto vreme, većina pravaških političara je napustila ideju o štokavskom, kajkavskom i čakavskom narečju kao istorijskim nacionalnim govorima etničkih Hrvata. Do tada, pravaška ideologija je pod ujedinjenom Hrvatskom podrazumevala čitavu južnoslovensku teritoriju od Triglava do Lovćena i od Jadrana do reka Drine i Drave. Dakle, na čitavom ovom geografskom prostoru živeo je navodno isključivo hrvatski narod koji je govorio kajkavskim, čakavskim i štokavskim dijalektom (dijalekatska trihotomija hrvatske nacije), upotrebljavao latinicu i ćirilicu kao svoja nacionalna pisma (pored glagoljice) i bio podeljen na osnovu veroispovesti na katoličke, pravoslavne i muslimanske Hrvate.

Tek nakon napuštanja ovakve ideologije čiji je idejni tvorac bio osnivač Hrvatske stranke prava - Ante Starčević - sredinom XIX veka, Srbi iz Trojednice su pristali na političku saradnju sa Hrvatima protiv zajedničkih neprijatelja - Beča i Pešte. Napredni hrvatski političari iz Dalmacije kako iz redova Hrvatske narodne stranke tako i iz redova Hrvatske stranke prava su 1903. shvatili da je sloga sa dalmatinskim Srbima garancija za popravljanje političko-ekonomskog položaja ove austrijske provincije. Razlog za hrvatsko-srpsku slogu su političari "novog kursa" objašnjavali etničko-jezičkom identičnošću ova dva naroda, ali identičnošću na ravnopravnim osnovama, ističući da se radi o hrvatsko-srpskom narodu kome je zajednički hrvatsko-srpski jezik koji se piše latiničnim i ćiriličnim pismom. Ovaj hrvatskosrpski sporazum je konačno ostvaren na temeljima potpune ravnopravnosti na kojima je počivala Hrvatsko-srpska koalicija iz 1906. Političkim programom koalicije koji je formalno počivao na potpunom narodnom jedinstvu Hrvata i Srba koji sada zvanično govore jednim jedinstvenim hrvatsko-srpskim/srpsko-hrvatskim jezikom koji se piše ćirilicom i latinicom prestali su uglavnom svi dotadašnji sukobi između ova dva naroda.

Za političko-nacionalnu budućnost Dalmacije kao bitnom tekovinom "novog kursa" se pokazala sloga između hrvatskih i srpskih političkih stranaka. Na tom je iskustvu stvorena pogodna klima za dalju saradnju. Zajedničko delovanje je pak bilo moguće samo na principima priznavanja posebne nacionalne pripadnosti za oba naroda i njihovom paritetnom ravnopravnošću što se praktično moglo dokazati samo priznavanjem javne upotrebe posebnog jezika, pisma, vere i zastave $e^{126}$ za obe nacionalnosti. Slično sporazumu ova dva

\footnotetext{
${ }^{125}$ Narodni list, 45/13. 6. 1900, "Ustavna ili slobodna?"; Isto, 79/10. 10. 1900., "Pri komu je smutnja"; Isto, 101/29. 12. 1900., "Pri koncu godine". Pod katoličkim Hrvatima se podrazumevaju rimokatolički i unijatski govornici štokavskog narečja. Pravoslavni Hrvati su tzv. grčko-nesjedinjeni štokavci dok su se muslimanski (štokavski) Hrvati (iz Bosne i Hercegovine) kasnije nazivali "hrvatskim cvijećem".

${ }^{126} \mathrm{U}$ periodu pre Hrvatsko-srpske koalicije članovi Hrvatske stranke prava su srpsku zastavu pogrdno nazivali "vlaškom krpom". Hrvatska zastava se, inače, kod mnogih Srba sa obe strane Drine od "milošte" naziva "smradovnica" iako je tzv. "šahovnica" (bez grba) u stvari "pozajmljena" iz Srbije. Naime, po Sretenjskom Ustavu Knjaževine Srbije iz 1835. g. za državnu zastavu je proglašena trobojnica (trikolorka) sa crvenom, belom i plavom bojom u horizontalnom aranžmanu i sa grbom knjaževine na sredini bele trake. Prema Članu 4.-om Ustava Knjaževine Srbije iz 1835. g. "Grb narodni srpski predstavlja krst na crvenom polju, a među krakovima krsta po jedno ognjilo okrenu-
} 
stranačka kluba iz Dalmacije, članovi Hrvatsko-srpske koalicije su u svemu i u svim krajevima Hrvatske-Slavonije izjednačavali srpski narod sa hrvatskim, srpski jezik sa hrvatskim jezikom, ćirilicu sa latinicom. Prevashodno odustajanjem od politike ispolitizovanog hrvatskog državnog prava nestao je i osnovni ideološki razlog za poricanje srpske nacionalne posebnosti u Trojednici. Time su prvi put u jugoslovenskoj istoriji postavljeni čvrsti temelji za hrvatsko-srpsku nacionalnu slogu i saradnju. Tek tada je moglo da nastupi pravo vreme istinskog jugoslovenstva koje je ne samo bilo oslobođeno austrofilskih osećanja već i direktno upereno protiv Austro-Ugarske i njene politike prema Južnim Slovenima. Možemo da zaključimo da je pitanje jezika i pisma Hrvata i Srba koje je u čitavom XIX veku predstavljalo jednu od glavnih jabuka razdora između ova dva naroda u Trojednici, početkom XX veka postalo njegovim pravilnim (političkim ali ne i filološkim) rešavanjem kamen temeljac nacionalne sloge Hrvata i Srba i njihovog zajedničkog nacionalno-političkog rada. ${ }^{127}$

\section{Literatura}

[1] Kontler L., Millenium in Central Europe. A History of Hungary, Szeged, 1999.

[2] Pavličević D., Povijest Hrvatske. Drugo, izmijenjeno i prošireno izdanje, Zagreb, 2000.

[3] Polić M., Ban Dragutin grof Khuen Héderváry i njegovo doba, Zagreb, 1901.

[4] Korespondencija Stjepana Radića, knjiga 1, Zagreb, 1936.

[5] Milosavljević P., Sistem srpske književnosti, Beograd, 2000.

[6] Moguš M., Povijest hrvatskoga književnoga jezika, Zagreb, 1993.

[7] Bakotić L., Srbi u Dalmaciji od pada Mletačke republike do Ujedinjenja, Beograd, 1939.

[8] Kann R. A., A History of the Habsburg Empire 1526-1918, Berkeley-Los Angeles-London, 1977.

[9] Vermes G. P., "South Slav Aspirations and Magyar Nationalism in the Dual Monarchy", Banac I., Ackerman G., Szporluk R. (eds.), Nations and Ideology. Essays in Honor of Wayne S. Vucinich, New York, 1981.

[10] Pavličević D., Povijest Hrvatske. Drugo, izmijenjeno i prošireno izdanje, Zagreb, 2000.

[11] Kršnjavi I., Zapisci, knjiga I, Zagreb, 1927.

[12] Seton-Watson R. W., The Southern Slav Question, London, 1911.

[13] Arhiv Hrvatske u Zagrebu, Predsednički spisi zemaljske vlade, "Sreski načelnik iz Dvora velikom županu Budi Budisavljeviću, Dvor, 25. decembar, 1903.”, kutija 648, dokument 2801, 1903.

[14] Krestić Đ. V., Građa o Srbima u Hrvatskoj i Slavoniji (1848-1914), knjiga II, Beograd, 1995.

[15] Perić I., Povijest Hrvata, Zagreb, 1997.

[16] Miladinović Z., Tumač povlastica, zakona, uredaba i drugih naređenja srpske narodne crkvene avtonomije u Ugarskoj, Hrvatskoj i Slavoniji, Novi Sad, 1897.

[17] Krestić Đ. V. - Ljušić R., Programi i statuti srpskih političkih stranaka do 1918. godine, Beograd, 1991.

[18] Vučetić I., Zbirka uredaba u stvarima srpske pravoslavne narodno-crkvene avtonomije, Novi Sad, 1897.

to k krstu. Sav grb opasan je zelenim vjencem s desne strane od rastova, a sa leve od maslinova lista" (Mladićević V. Z., Simboli srpske državnosti: Kratak istorijski pregled heraldičkog razvoja u Srba, Kragujevac, 1994, 60).

${ }^{127}$ O srpskom nacionalnom gledištu na pitanje hrvatsko-srpskih jezičkih razmirica videti: Ruvarac D., Evo, šta ste nam krivi! Posvećeno "Obzoru”, Zemun, 1895. 
[19] Milićević A., "O iseljavanju, osobitim obzirom na prilike u Dalmaciji", Glasnik Matice dalmatinske, knjiga II, sveska 1, Zadar, 1903.

[20] Artmann F., Wirtschaftliche Faktoren in Dalmatien, Wien, 1907.

[21] Smodlaka J., Dva govora što ih je izrekao dr Josip Smodlaka, narodni poslanik u hrvatskom saboru u Zadru, dne 15. i 22. Srpnja, Zadar, 1902.

[22] Majstorović I., "Besjeda biračima pri pohodu izbornog kotara, listopada 1902", Zadar, 1903.

[23] Pavlinović M., "Hrvatstvo, srpstvo, slovinstvo", Pjesme i besjede, Zadar, 1873.

[24] Rade Petrović, Nacionalno pitanje u Dalmaciji u XIX. stoljeću, Sarajevo-Zagreb, 1982.

[25] Barić H., Izabrani članci Antuna Fabrisa, Beograd, 1940.

[26] Delich S., L'irrendentismo italiano in Dalmazia. Secondo i documenti segreti della polizia austriaca, Roma, 1924.

[27] Novak V., "The Slavonic-Latin Symbiosis in Dalmatia During the Middle Ages", Slavonic and East European Review, XXXII, № 78, 1953.

[28] Foretić D., "O etničkom sastavu stanovništva Dalmacije u XIX st. s posebnim osvrtom na stanovništvo talijanske narodnosti", Dalmacija 1870, Zadar, 1972.

[29] "Pred velikom odgovornosti"; Novi list, 1/1904.

[30] Šepić D., "Jugoslavenski pokret i Milan Marjanović 1901-1919", Zbornik Historijskog instituta JAZU, 3, Zagreb, 1960.

[31] Ministerium des Inneren, Prasidiale, 22 Dalmatien, Verwaltungsarchiv, Oesterreichisches Staatsarchiv, Wien, 1903, 1567, Zadar, 15. 6. 1903.

[32] Trumbić A., Suton Austro-Ugarske i Riječke rezolucije, Zagreb, 1936.

[33] Horvat J., Politička povijest Hrvatske, Zagreb, 1990.

[34] Vojvođanski muzej, Radikalna stranka, "Đorđe Krasojević upravama hrvatskih opozicionih stranaka nudi izborni sporazum za zemaljski sabor, Sremski Karlovci, 3./16. januar 1905.", broj 4037/27.

[35] Arhiv Srpske Akademije nauka i umetnosti, Sremski Karlovci, "Zapisnik sednice Školskog saveta, Sremski Karlovci, 3./16. avgusta 1905.", Školski savet, broj 464/1905.

[36] Arhiv Hrvatske u Zagrebu, Predsednički spisi zemaljske vlade, "Hrvatsko građanstvo Gospića velikom županu Tomi Kraljeviću, Gospić, 7. septembar 1905.", kutija 661, dokument 3176 Pr. 1905.

[37] Arhiv Srpske Akademije nauka i umetnosti, Fond dr. F. Nikića, "Sporazum sa Hrvatima, Zapisnik sastavljen u uredu Zemaljskog odbora u Zadru, dana 14./1. novembra 1905.", broj 14.528; Dubrovnik, 47/1905.

[38] Arhiv Ante Trumbića, Znanstvena knjižnica u Splitu, M 415.

[39] "Proglas hrvatske i srpske opozicije", Novi Srbobran, 15. decembar 1905.

[40] Gross M., Vladavina Hrvatsko-srpske koalicije 1906-1907, Beograd, 1960.

[41] Gowland D., Dunphy R., Lythe Ch., The European Mosaic, Harlow, 2006.

[42] Mladićević V. Z., Simboli srpske državnosti: Kratak istorijski pregled heraldičkog razvoja u Srba, Kragujevac, 1994.

[43] Ruvarac D., Evo, šta ste nam krivi! Posvećeno “Obzoru”, Zemun, 1895. 